\title{
Reinforced soft soil by CSV with/without polypropylene fiber: experimental and numerical analysis
}

\author{
Souadeuk Anouar, Boudaoud Zeineddine \\ Faculty of science and applied sciences, Department of Civil Engineering, Larbi Ben M'bidi University, Oum El Bouaghi, Algeria. \\ souadeukanouar@outlook.fr,.zboudaoud@yahoo.fr
}

\begin{abstract}
Columns of mixed soil-sand-cement (CSV) is one of the most unused methods for reinforcing soils. To this end, in this paper, consolidated drained triaxial compression tests were carried out to investigate the effectiveness of CSV to reinforce the soft soil using varied combinations of CSV materials. Some of the tests were unsuccessful which can be labelled to the high quantity of cement. For this reason, an analysis with the design of experiments is established as an alternative method to estimate the equations for the sake of determining the results of the failed tests. Then, a numerical analysis using PLAXIS 3D has been used for studying the behaviour of soils reinforced by CSV under the embankment. Furthermore, a validation of the results with the analytic method has been properly presented. The experimental results have indicated that the efficiency of the reinforcement of the soft soil by CSV provides satisfying results, namely the less quantity of soft soil on CSV materials (with/without polypropylene fiber) the better the deviatoric stress, axial strain, effective cohesion, effective friction angle, and modulus of elasticity. Additionally, adding polypropylene fiber to CSV materials enhances the obtained results. Based on the numerical results, the reinforcement by CSV has noticeably reduced the displacements and improved security factors.
\end{abstract}

KEYWORDS. Reinforced soil; Triaxial; PLAXIS 3D; Method design of experiments (DOE); Columns soil-sand-cement (CSV); Polypropylene fiber.

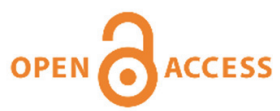

Citation: Anouar, S., Zeineddine, B., Reinforced soft soil by CSV with/without polypropylene fiber: experimental and numerical analysis, Frattura ed Integrità Strutturale, 59 (2022) 374-395.

Received: 05.07.2021

Accepted: 12.11 .2021

Published: 01.01.2022

Copyright: (C) 2022 This is an open access article under the terms of the CC-BY 4.0, which permits unrestricted use, distribution, and reproduction in any medium, provided the original author and source are credited.

\section{INTRODUCTION}

$\mathrm{T}$ echnically speaking, soft soils have high compressibility, low undrained shear strength and relatively reduced permeability $[1,2]$. Hence, these drawbacks are risky since they broaden the consolidation time and badly affect the deformation development in the long term [3,4], and the slope instability which occurs during earthquakes [5,6].

These events are similar to what happened on Friday (August 7th, 2020) in a city called Mila, situated in Algeria - North Africa [7]. As CSV has been associated with the potential benefits of reducing settlement and increasing the bearing capacity of soil [8,9], we purposefully investigated its utility in reinforcing the soft ground of Mila. 
CSV are columns consisting of mixed soil-sand-cement. Despite the benefits that have been associated with it, CVS is not a commonly used method. In the first part of this paper, triaxial tests have been used to study the efficiency of CSV for reinforcing soft soil with varied combinations. The materials of CSV consisting of sand-cement are mixed during the reinforcement with different quantities of soft soil. For this reason, three percentages (25\%, 50\% and $75 \%$ of soft soil contents in CSV materials are studied.

Authors [10-14], have noticed that the added cement triggered a sudden fall in the residual strength. To tackle this problem, PP fiber is purposefully used, as it can greatly enhance the residual strength [15-18]. Therefore, the added PP fiber $(0.5 \%$ and $1 \%$ ) on materials of CSV is thoroughly analysed.

As previously mentioned, among the three percentages of soft soil contents $(25 \%, 50 \%$ and $75 \%)$ on CSV materials, one of them (25\% soft soil content) has been proved to be experimentally undoable due to the high quantity of cement $(15 \%$ $22.5 \%$ ). For that, in the second part, an analysis with design of experiments (DOE) is established to estimate the mathematical models which open the way, by exploration, to the determination of the results of failed tests. The design of experiments techniques has been widely used to successfully deal with engineering problems [19-22].

In the third section, numeric models with PLAXIS 3D are used for study the behaviour of soils reinforced by CSV under the embankment. A comparative study between analytical and numerical results is made for the sake of validating the numerical results. Furthermore, the behaviour of soils with/without CSV is studied. Finally, a conclusion and potential future works conclude this paper.

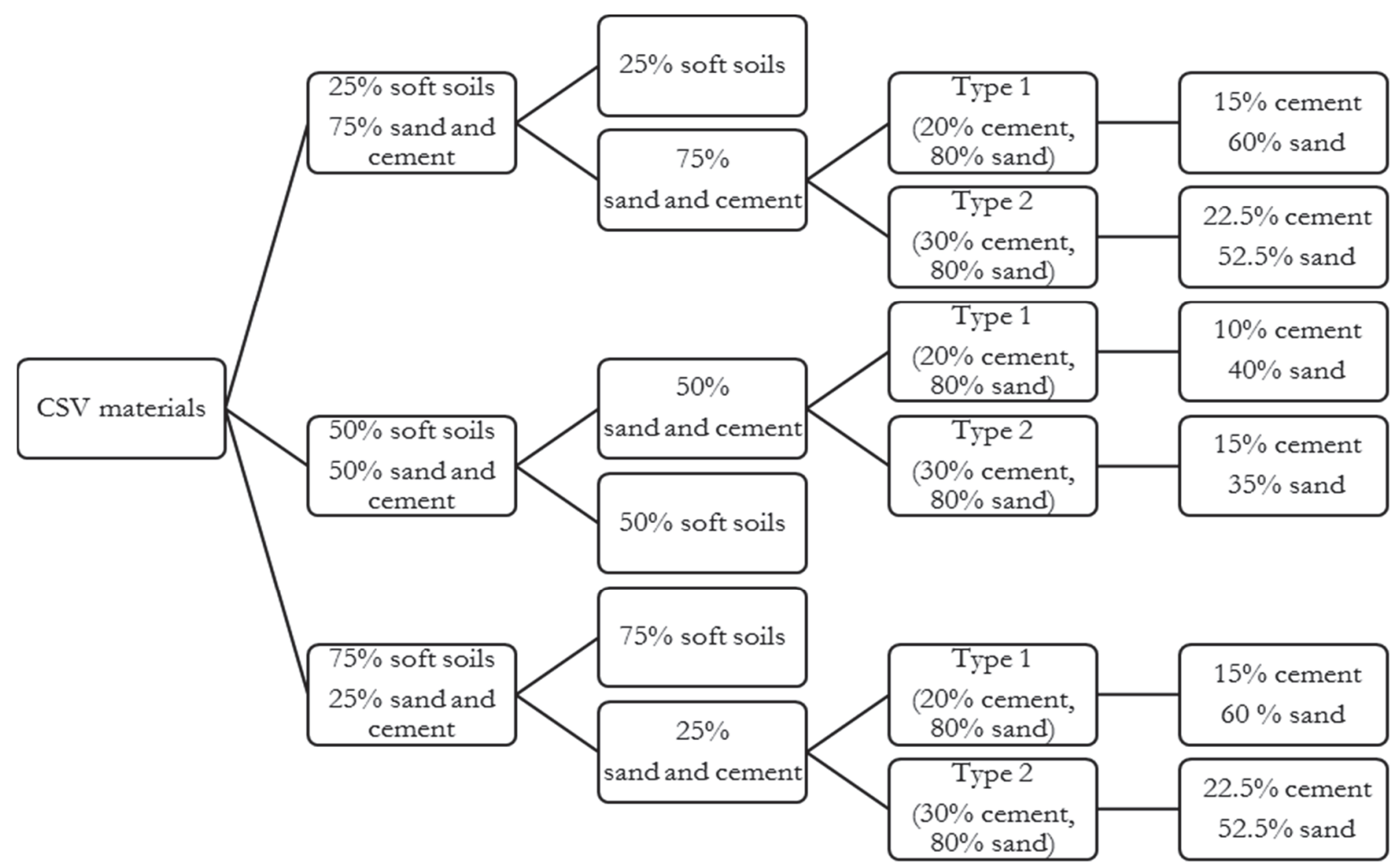

Figure 1: The percentage of the (sand-cement-soil) use in materials of samples.

\section{EXPERIMENTAL}

he experimental process consists of 18 triaxial compression tests (CD) after the samples have been cured for 28 days under cell pressure (CP) 100, 200 or $300 \mathrm{KPa}$. The used triaxial machine to study the samples is depicted in Fig. 4. In these experimental tests, the aim was to study the efficiency of CSV for reinforcing the soft soil and to investigate the effect of soft soil contents $(25 \%, 50 \%$ and $75 \%)$ on materials of CSV with/without PP fiber. Furthermore, for each percentage, two ratios have been used, which have an impact on the quantity of sand and cement. The first ratio (type 1) contains $20 \%$ of cement and $80 \%$ of sand. The second one (type 2 ) has $30 \%$ of cement and $70 \%$ of sand [8], as it is explained 
in Fig. 1 and Tab. 1. The whole contents of materials are calculated with respect to the volume of the sample as mentioned in Eqn. 1.

$$
m=V_{s} \times(\%) \times \rho
$$

$m$ : Mass of materials (sand, soil, cement and PP fiber).

$V_{s}:$ Volume of the sample (The dimension of used samples, $35 \mathrm{~mm}$ in diameter and $70 \mathrm{~mm}$ in height).

$\rho:$ Density of materials.

$\%$ : Percentages of materials in the volume of sample.

In the present paper, three types of materials have been used, namely, soils (soft soil and sand), PP fiber and cement. In essence, the soft soil has been extracted from the city of Mila after the occurrence of the earthquake (August $7^{\text {th }}, 2020$ ), as it is shown in Fig. 2. Experimental tests in the laboratory have shown that the soil of MILA is soft soil. The studied soft soil consists of $13.73 \%$ water, degree of saturation $91.04 \%$, dry unit weight $18.83 \mathrm{kN} / \mathrm{m}^{3}$, saturated unit weight $21.48 \mathrm{kN} / \mathrm{m}^{3}$, liquid limit of $45.97 \%$, plasticity index of $17 \%$, specific gravity of 2.771 , and compression index 0,19 . Regarding Sand, it has been taken from a city called Ouad Zhour, which is located in Skikda. It is mainly composed of a dry unit weight $17 \mathrm{kN} / \mathrm{m}^{3}$, saturated unit weight $20 \mathrm{kN} / \mathrm{m}^{3}$, specific weight $1.6 \mathrm{~g} / \mathrm{cm}^{3}$, uniformity coefficient 1.47 , curvature coefficient 0.94 , and the value of blue methylene is 0.49 . Grain size distribution curves for the sand and soft soils are depicted in Fig. 3 .

\begin{tabular}{ccccc}
\hline SSC \% & $\begin{array}{c}\text { Types } \\
\text { (Ratios) }\end{array}$ & SC $\%$ & CC $\%$ & Abbreviation \\
\hline \multirow{2}{*}{25} & 1 & 60 & 15 & 25.T1.F0;0,5;1 \\
& 2 & 52.5 & 22.5 & 25.T2.F0;0,5;1 \\
50 & 1 & 40 & 10 & 50.T1.F0;0,5;1 \\
& 2 & 35 & 15 & 50.T2.F0;0,5;1 \\
75 & 1 & 20 & 5 & 75.T1.F0;0,5;1 \\
& 2 & 17.5 & 7.5 & 75.T2.F0;0,5;1 \\
\hline
\end{tabular}

Table 1: The quantity of columns CSV materials.

The PP fiber has a circular section, $18 \mathrm{~mm}$ length, stretching 150-350\%, specific weight $0.91 \mathrm{~g} / \mathrm{cm}$, melting temperature $165^{\circ} \mathrm{C}$, tensile strength $320-400 \mathrm{MPa}(\mathrm{N} / \mathrm{mm} 2)$, electrical conductivity <103 Siemens, Young's modulus $3500-3900 \mathrm{MPa}$, and water absorption $0 \%$. The last used material is the cement (CPJ-CEM II 42.5), with specific weight $3.1 \mathrm{~g} / \mathrm{cm}^{3}$, residues $2.28 \%$, insoluble $2.41 \%, \mathrm{PAF}_{975} 57.22 \%, \mathrm{CaO} 27.83 \%, \mathrm{Fe}_{3} \mathrm{O}_{3} 3.12 \%, \mathrm{MgO} 0.94 \%, \mathrm{SO}_{3} 2.02 \%$, and $\mathrm{CaO} 0.88 \%$.

The triaxial compression tests (CD) have been carried out through six phases following the procedure listed in ASTM [26,27].

Phase 1: Soil-sand-cement with/without PP fiber are mixed in a dry state using ordinary tools of the mixture.

Phase 2: Percolation with water. In this step, the water is introduced through the bottom drainage line and is allowed to seep up through the specimen under a hydraulic gradient. This is intended to flush the air out through the top drainage line, thereby, the specimen is saturated with water.

Phase 3: The back-pressure, as well as the cell pressures, are applied incrementally and at each time the Skempton pore pressure parameter $(\beta)$ is verified, the samples are saturated when the value of $\beta$ is superior $95 \%$.

$$
\beta=\Delta \mathrm{u} / \Delta \sigma_{3} \text { is }>95 \%
$$

\section{$\beta:$ Skempton pore pressure parameter.}

$\Delta \mathrm{u}$ : The resultant change in pore pressure obtained under the undrained isotropic compression condition.

$\Delta \sigma_{3}:$ The isotropic cell pressure.

Phase 4: The specimen undergoes an isotropic consolidation, under a CP of 100, 200 or $300 \mathrm{kPa}$. The consolidation ends up when the volume variation takes constant values.

Phase 5: The samples of CSV materials are cured for 28 days under a CP of 100, 200 or $300 \mathrm{kPa}$. 
Phase 6: Shear loading is applied with respect to a constant confining pressure under drained conditions with the presence of an axial displacement rate of $0.02 \mathrm{~mm} / \mathrm{min}$ to specimen failure.

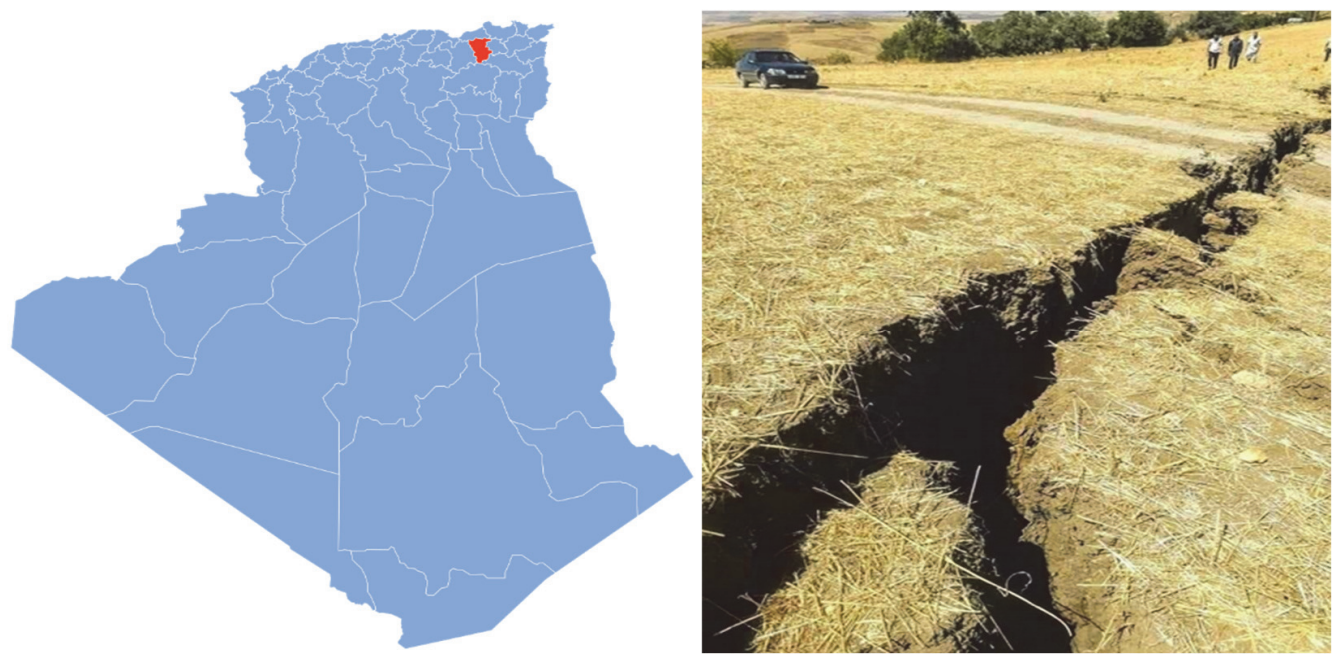

Figure 2: (a) located Mila (situated in Algeria, North Africa), (b) the slop of Mila soil after the earthquake (August 7, 2020).

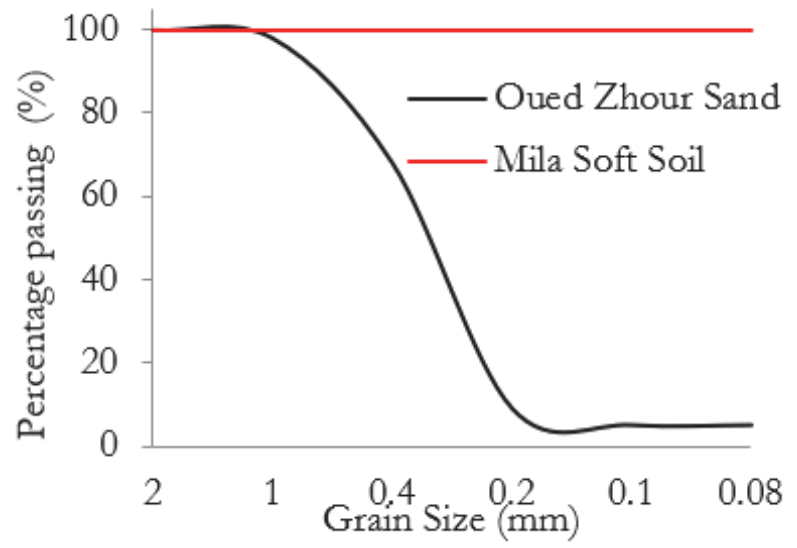

Figure 3: Grain size distribution curves for the sand (Oued Zhour) and soft soil (Mila).

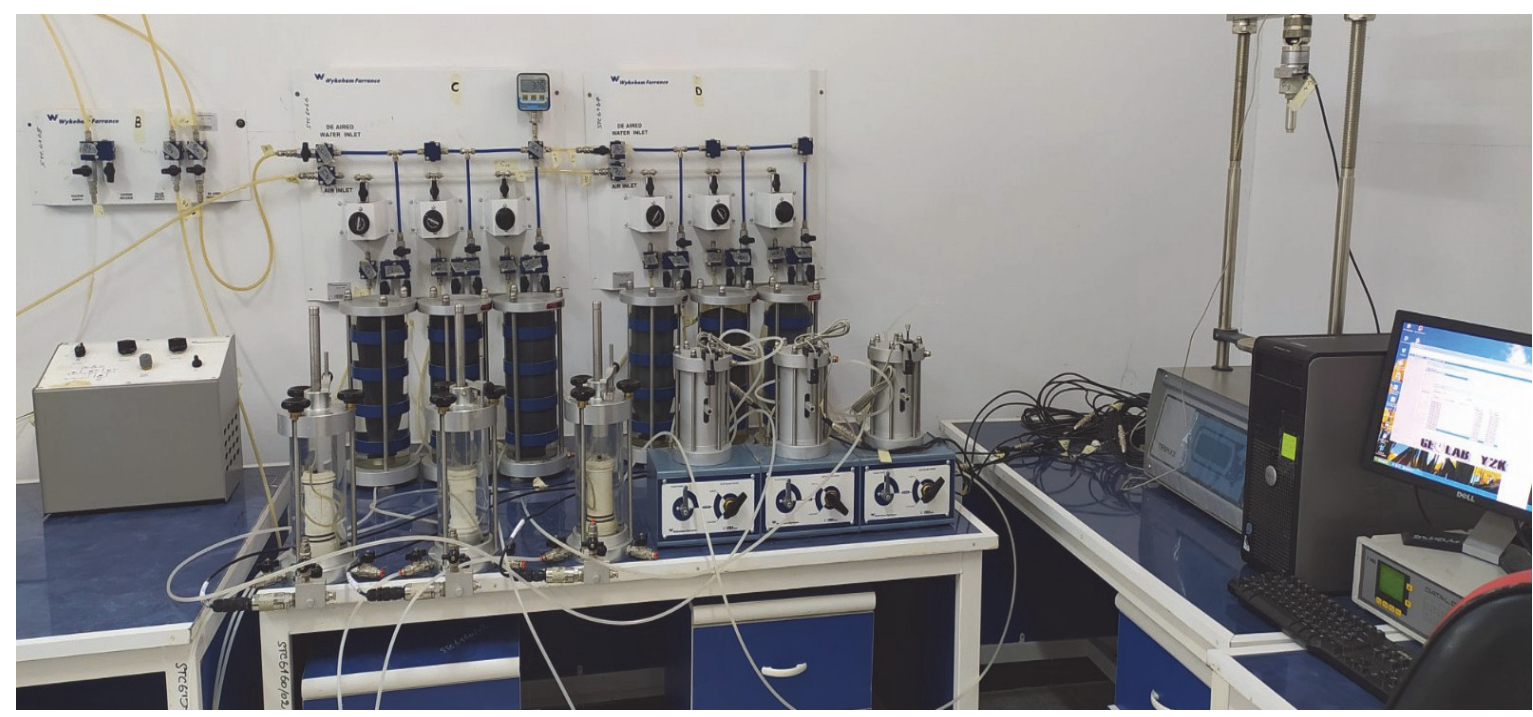

Figure 4: The triaxial machine. 
Results and discussed of triaxial compression tests

The variation of deviator stress with shear strain for soft soil of Mila is illustrated in Fig. 5. The following Figs. 7-10 show the variation of deviator stress with shear strain for the materials of CSV. For the upper side of the last-mentioned figures, a CP of $100 \mathrm{kPa}$ is revealed, the center side and the lower side illustrate a specimen that undergoes a CP of $200 \mathrm{kPa}, 300$ $\mathrm{kPa}$, respectively. In Fig. 6 (a) and (b), it is depicted that the variation of the effective friction angle and the effective cohesion in function of PP fiber content. The results tests are summarised in Tab. 2.

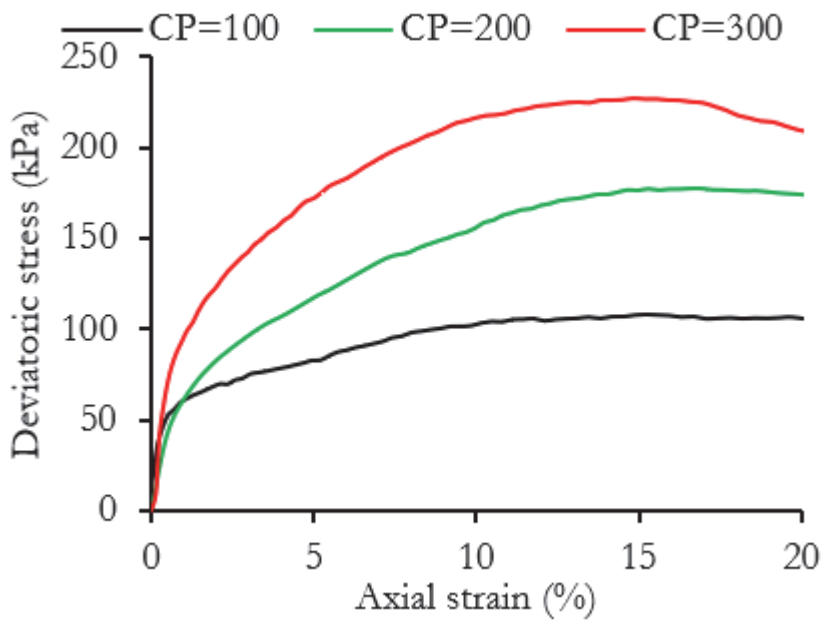

Figure 5: Stress-strain behaviour of soft soil with $\mathrm{CP}=100,200$ and $300 \mathrm{kPa}$.

\begin{tabular}{|c|c|c|c|c|c|c|c|c|c|c|c|c|}
\hline \multirow{2}{*}{$\begin{array}{l}\text { SSC } \\
(\%)\end{array}$} & \multirow{2}{*}{$\begin{array}{l}\text { SC } \\
(\%)\end{array}$} & \multirow{2}{*}{$\begin{array}{l}\mathrm{CC} \\
(\%)\end{array}$} & \multirow{2}{*}{$\begin{array}{l}\text { FC } \\
(\%)\end{array}$} & \multirow{2}{*}{$\begin{array}{c}\boldsymbol{C}^{\prime} \\
(\mathrm{kPa})\end{array}$} & \multirow[b]{2}{*}{$\varphi^{\prime}$} & \multirow{2}{*}{$\begin{array}{c}\mathrm{E} \\
(\mathrm{kPa})\end{array}$} & \multicolumn{3}{|c|}{ Deviatoric stress $(\mathrm{kPa})$} & \multicolumn{3}{|c|}{ Axial strain (\%) } \\
\hline & & & & & & & $\begin{array}{c}\mathrm{CP}= \\
100 \mathrm{kPa}\end{array}$ & $\begin{array}{c}\mathrm{CP}= \\
200 \mathrm{kPa}\end{array}$ & $\begin{array}{c}\mathrm{CP}= \\
300 \mathrm{kPa}\end{array}$ & $\begin{array}{c}\mathrm{CP}= \\
100 \mathrm{kPa}\end{array}$ & $\begin{array}{c}\mathrm{CP}= \\
200 \mathrm{kPa}\end{array}$ & $\begin{array}{c}\mathrm{CP}= \\
300 \mathrm{kPa}\end{array}$ \\
\hline 100 & 0 & 0 & 0 & 20.17 & 13.29 & 52.42 & 109.64 & 177.69 & 229.30 & 19.74 & 17.59 & 16.62 \\
\hline 75 & 20 & 5 & 0 & 72.52 & 33.63 & 579.87 & 555.35 & 869.33 & 1046.42 & 3.26 & 3.92 & 4.76 \\
\hline 75 & 20 & 5 & 0.5 & 128.49 & 38.78 & 761.78 & 1011.69 & 1383.44 & 1680.65 & 3.46 & 4.56 & 5.14 \\
\hline 75 & 20 & 5 & 1 & 154.35 & 37.49 & 828.69 & 1108.21 & 1359.02 & 1729.61 & 6.13 & 7.37 & 7.93 \\
\hline 75 & 17.5 & 7.5 & 0 & 89.109 & 40.36 & 1497.34 & 857.76 & 1276.33 & 1589.98 & 3.07 & 3.26 & 3.89 \\
\hline 75 & 17.5 & 7.5 & 0.5 & 142.24 & 42.78 & 1154.22 & 1436.14 & 1590.07 & 1600.95 & 3.21 & 3.91 & 4.05 \\
\hline 75 & 17.5 & 7.5 & 1 & 164.06 & 43.56 & 965.83 & 1534.27 & 1884.65 & 2413.78 & 6.05 & 7.07 & 7.35 \\
\hline 50 & 40 & 10 & 0 & 103.32 & 49.09 & 3174.47 & 1653.96 & 1864.54 & 2793.28 & 1.81 & 2.44 & 3.06 \\
\hline 50 & 40 & 10 & 0.5 & 166.09 & 47.47 & 1914.38 & 1753.96 & 1902.92 & 2939.28 & 2.67 & 2.94 & 3.64 \\
\hline 50 & 40 & 10 & 1 & 179.22 & 49.22 & 1727.24 & 2069.01 & 2802.63 & 3307.24 & 3.08 & 3.55 & 4.062 \\
\hline 50 & 35 & 15 & 0 & 164.43 & 49.11 & 3903.77 & 2013.53 & 2508.34 & 3241.64 & 1.23 & 1.91 & 2.99 \\
\hline 50 & 35 & 15 & 0.5 & 174 & 52.04 & 2399.53 & 2409.02 & 3101.05 & 3898.01 & 2.43 & 3.24 & 3.51 \\
\hline 50 & 35 & 15 & 1 & 182.61 & 52.6 & 1873.45 & 2630.34 & 3200.44 & 4153.68 & 3.19 & 3.48 & 3.63 \\
\hline
\end{tabular}


From Tab. 2, it is noticed that the comparison of the results of the reinforced soft soil to the non-reinforced soft soil has come up with the following results: deviatoric stress increases by $(+500 \%)$, effective cohesion by $(+259 \%)$, fraction angle by $(+153 \%)$, modulus of elasticity $\mathrm{E}_{50}$ by $(+1000 \%)$, and axial strain decreases by $(-83 \%)$, and it can be furtherly enhanced when adding the PP fiber in CSV materials. These satisfying results are mainly caused by the effect of cement and PP fiber. Interestingly, the effect of cement content in soils (clay or sand) with/without PP fiber has been previously studied [28-30], so the authors approximately found the same results. For the effect of PP fiber contents, which is studied by [33], authors have found that the maximum shear strength increases with the increment of PP fiber content.

Furthermore, the effect of soft soil contents on the materials of CSV with/without PP fiber, from Fig. 6 (a) and (b), the results show that both the effective friction angle and the effective cohesion increase with the decrease of the content of soft soil. However, when the PP fiber is added, the effective friction angle and the effective cohesion remarkably increase. Moreover, from the Figs. 7-10, and in comparison to Figs 7a, 8a, 9a and 10a (7a-10a), a decrease is observed in the soft soil content which leads to an increase of peak stress. Besides, the decrease of soft soil content in a specimen yields perfect plastic materials' behaviour. Afterwards, when adding the PP fiber to the CSV materials, the results show that the specimen at high cell pressure can develop more strain before reaching the peak stress. Similarly, the same results can be noticed from Figs. 7b-10b as well as from Figs 7c-10c; as found by [33-35], namely the addition of PP fiber yields a significant decrease in cemented samples at lower strains.

For the modulus of elasticity $\mathrm{E}_{50}$ from Tab. 2, the results show that the smaller quantities of soft soil on the materials of CSV are associated with improvement in the modulus of elasticity. When adding the PP fiber with a decreasing quantity of soft soil, a decrease as well as an increase in the obtained results are found, similarly in [36] and [34].

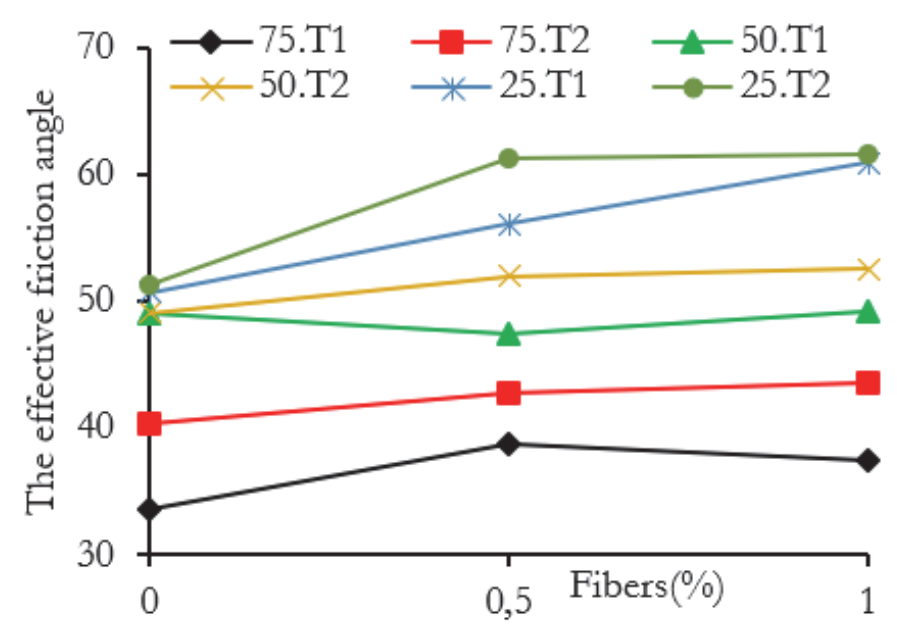

(a)

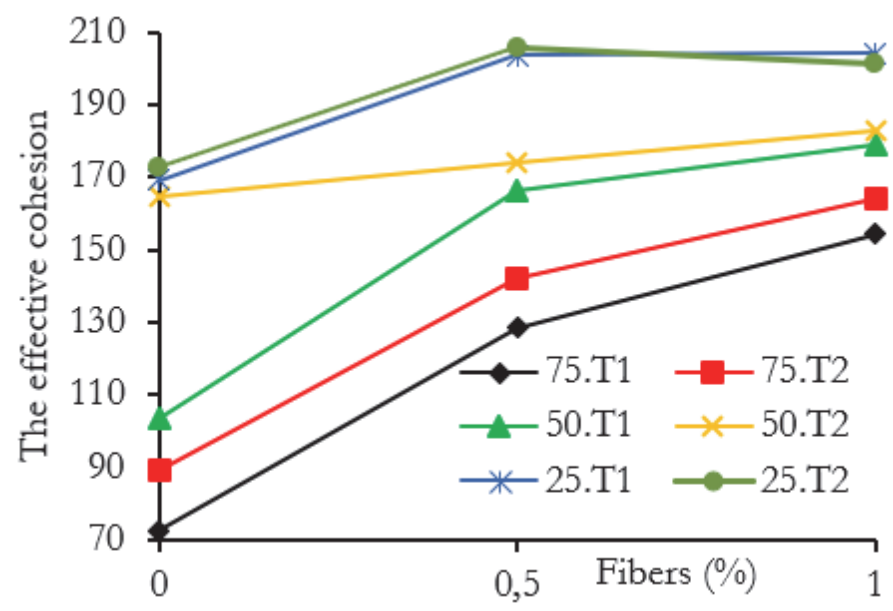

(b)

Figure 6: (a) The effective friction angle - PP fiber contents, (b) the effective cohesion - PP fiber contents. 
a) Cell pressure $(\mathrm{CP}=100 \mathrm{kPa})$.

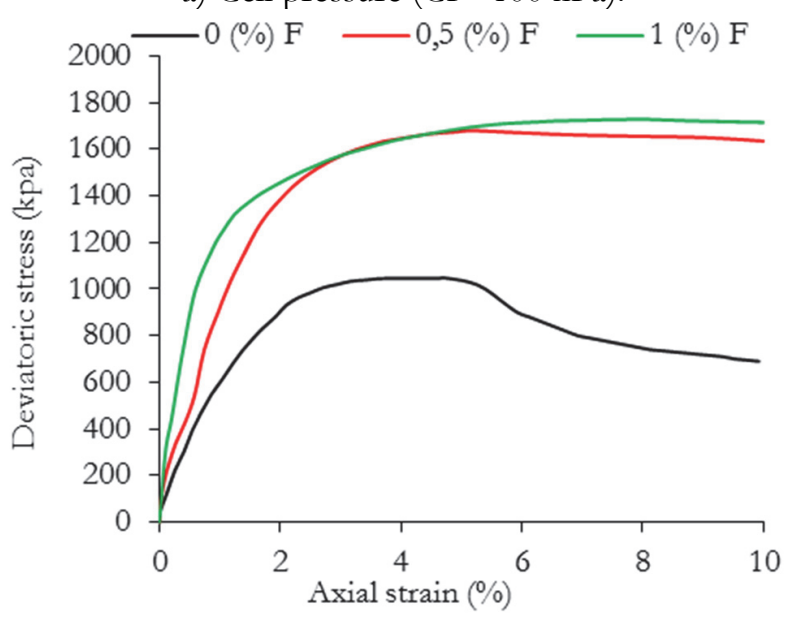

b) Cell pressure $(\mathrm{CP}=200 \mathrm{kPa})$.

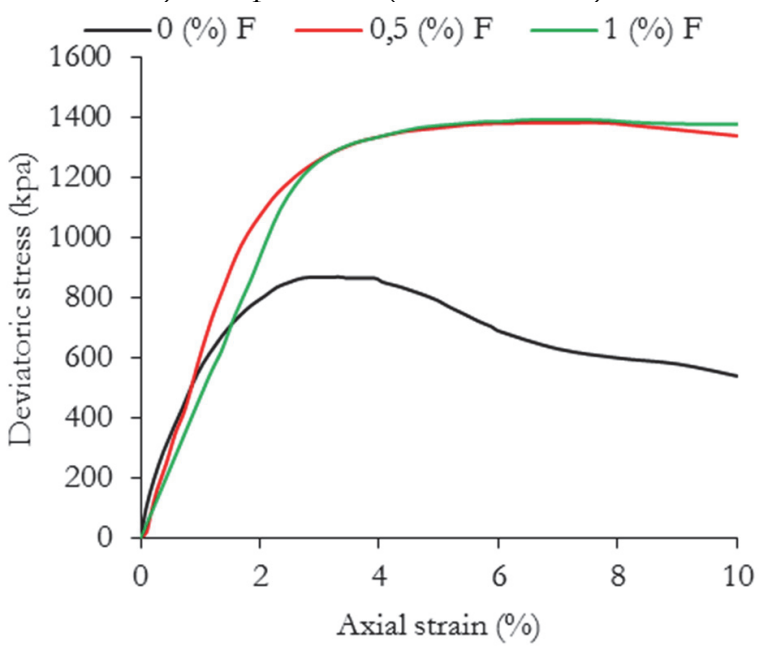

c) Cell pressure $(\mathrm{CP}=300 \mathrm{kPa})$.

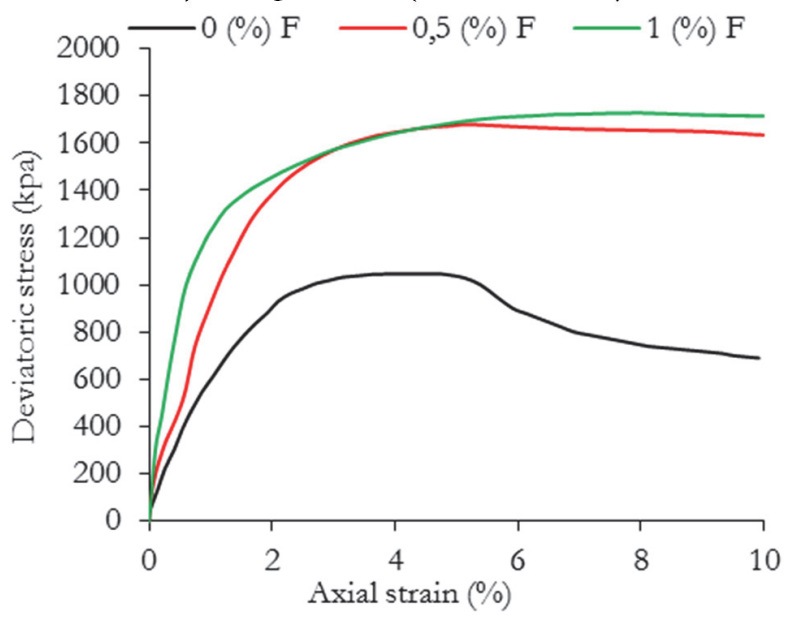

Figure 7: Stress-strain behaviour of samples (SSC $=75 \%$, $\mathrm{SC}=20 \%$ and $\mathrm{CC}=5 \%$ ). With different $\mathrm{CP}$. a) Cell pressure $(\mathrm{CP}=100 \mathrm{kPa})$.

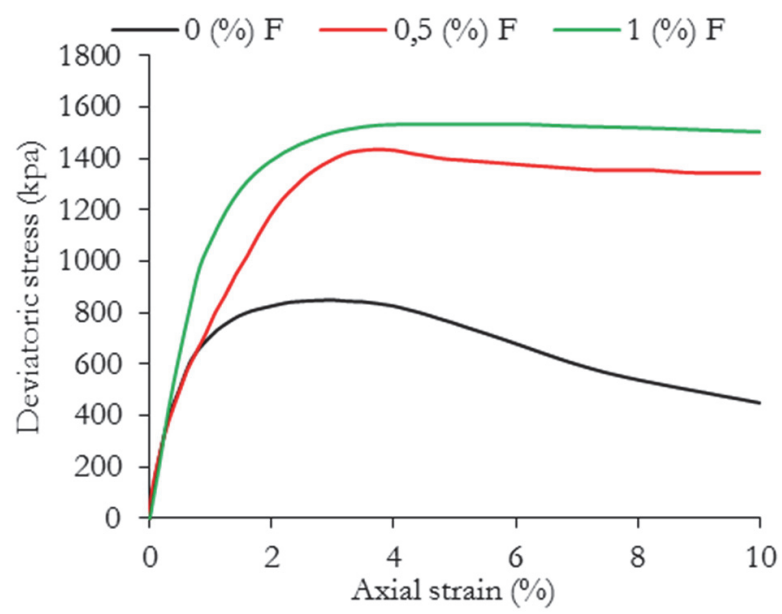

b) Cell pressure $(\mathrm{CP}=200 \mathrm{kPa})$.

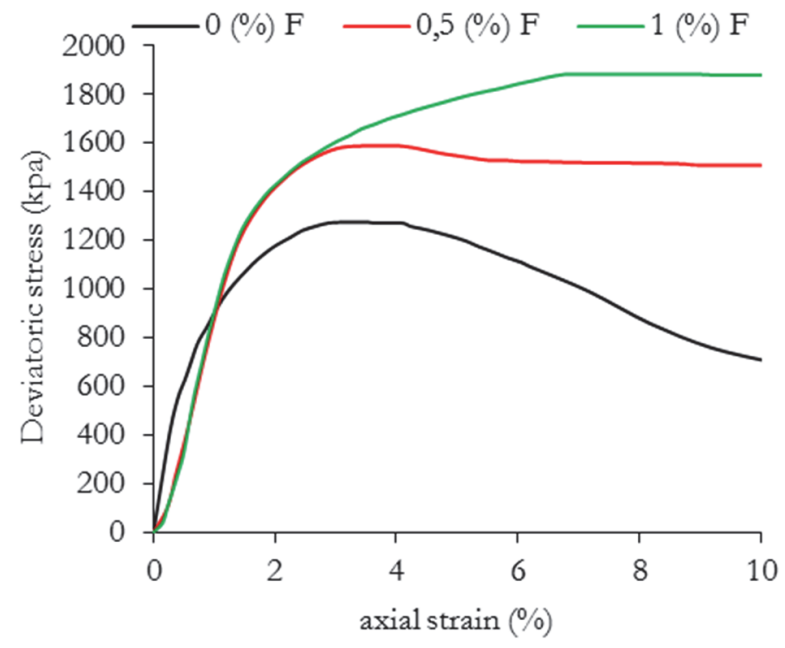

c) Cell pressure $(\mathrm{CP}=300 \mathrm{kPa})$.

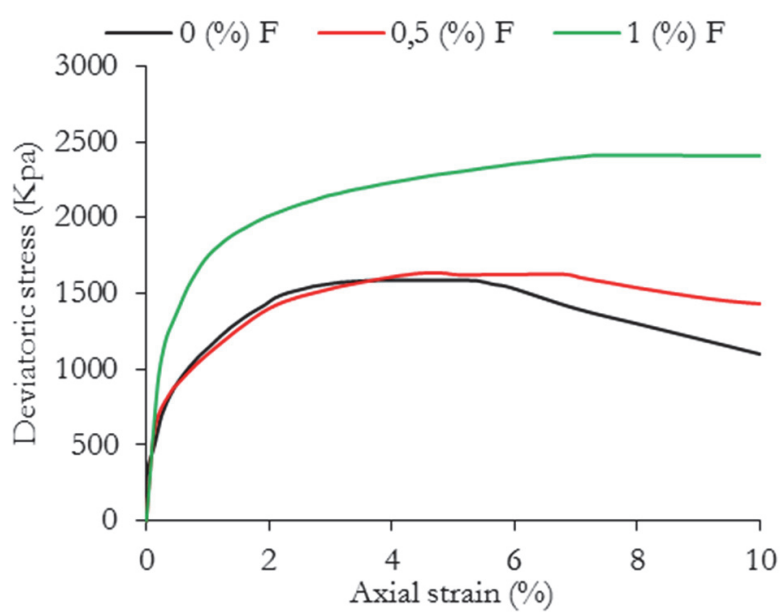

Figure 8: Stress-strain behaviour of samples ( $\mathrm{SSC}=75 \%$, $\mathrm{SC}=17.5 \%$ and $\mathrm{CC}=7.5 \%$ ). With different CP. 
a) Cell pressure $(\mathrm{CP}=100 \mathrm{kPa})$.

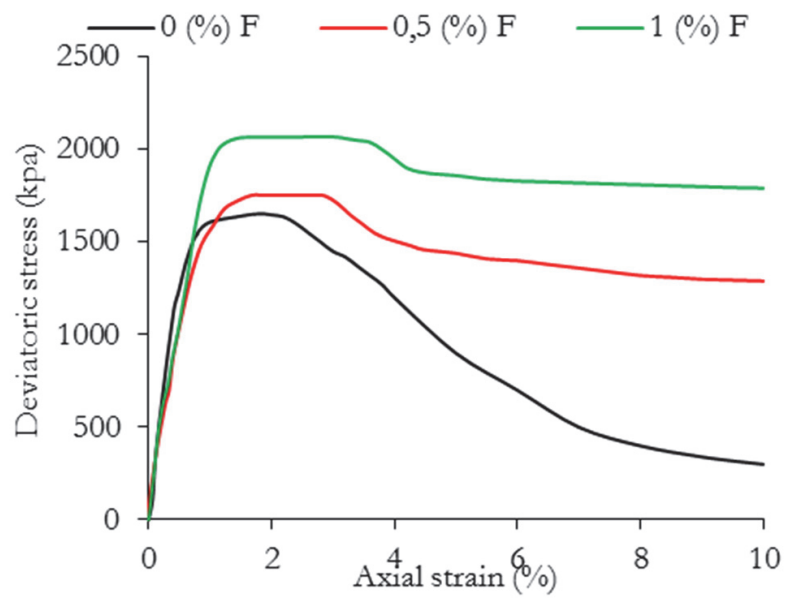

b) Cell pressure $(\mathrm{CP}=200 \mathrm{kPa})$.

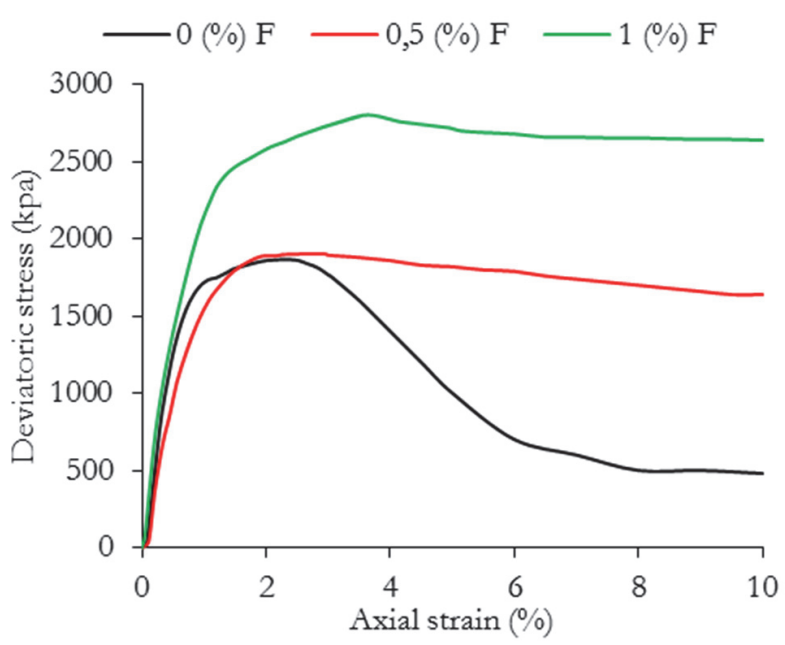

c) Cell pressure $(\mathrm{CP}=300 \mathrm{kPa})$.

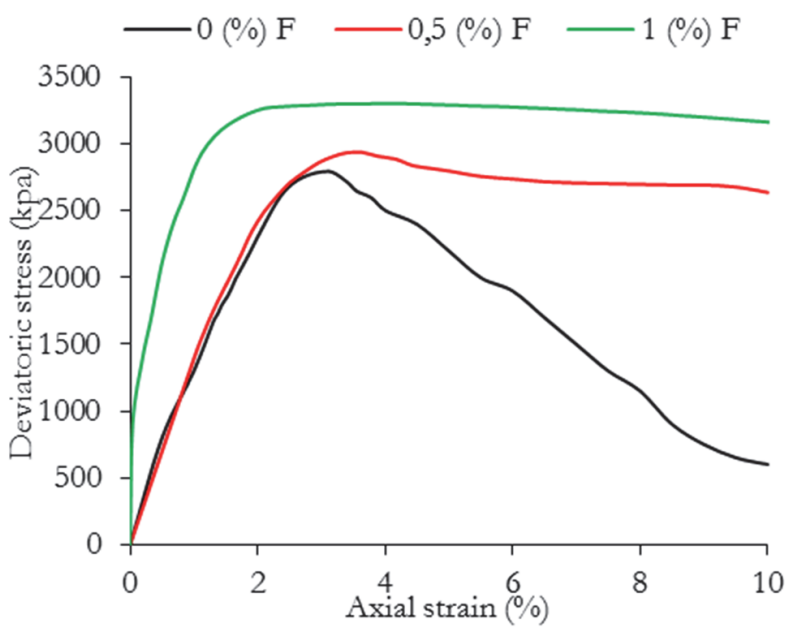

Figure 9: Stress-strain behaviour of samples (SSC $=50 \%$, $\mathrm{SC}=40 \%$ and $\mathrm{CC}=10 \%$ ), With different $\mathrm{CP}$. a) Cell pressure $(\mathrm{CP}=100 \mathrm{kPa})$.

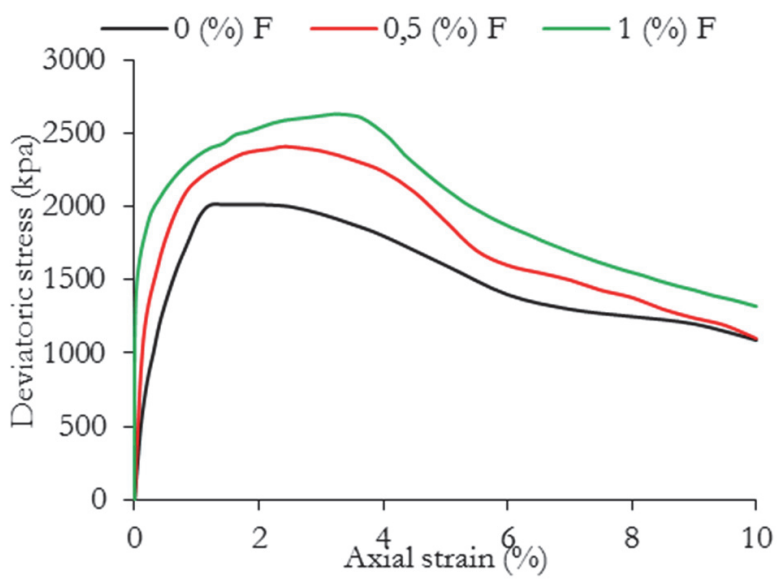

b) Cell pressure $(\mathrm{CP}=200 \mathrm{kPa})$.

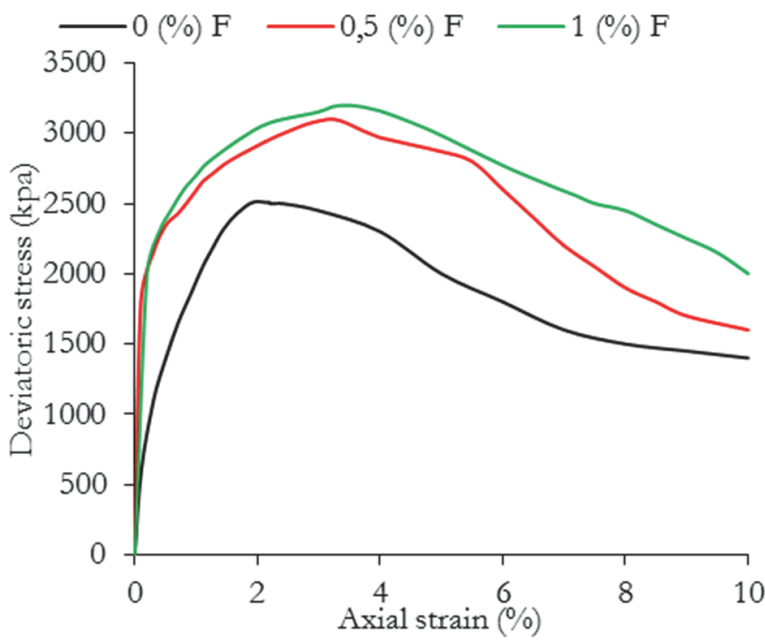

c) Cell pressure $(\mathrm{CP}=300 \mathrm{kPa})$.

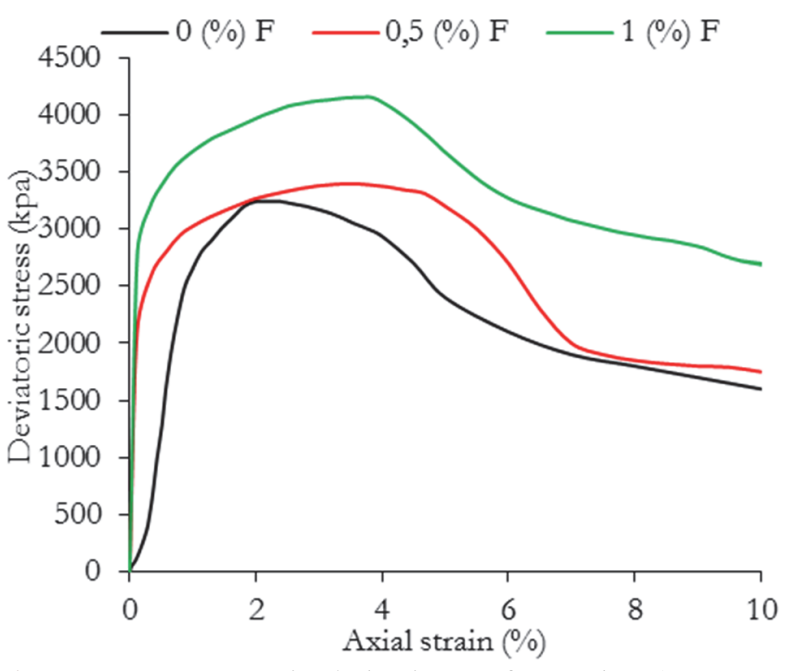

Figure 10: Stress-strain behaviour of samples ( $\mathrm{SSC}=50 \%$, SC $=35 \%$ and $\mathrm{CC}=15 \%$, With different $\mathrm{CP}$. 


\section{THE DESIGN OF EXPERIMENTS (DOE)}

A previously mentioned, for studying the effectiveness of soft soil contents on materials of CSV, among the three percentages of soft soil contents $(25 \%, 50 \%$ and $75 \%)$, one of them ( $25 \%$ soft soil content) has been proved to be experimentally undoable due to the high quantity of cement $(15 \%-22.5 \%)$, which causes the porous stones to be cracked as shown in Fig. 11. Alternatively, a design of experiments (DOE) is carried out. This plan has allowed us to establish predictive models. The experimental data as presented in Tab. 3, have been analysed by Minitab 19 by correlating each response variables (outputs): effective friction angle, effective cohesion and modulus of elasticity, with three inputs variables: soft soil contents, types of CSV materials, and PP fiber contents, which yields in Eqts 3-5.

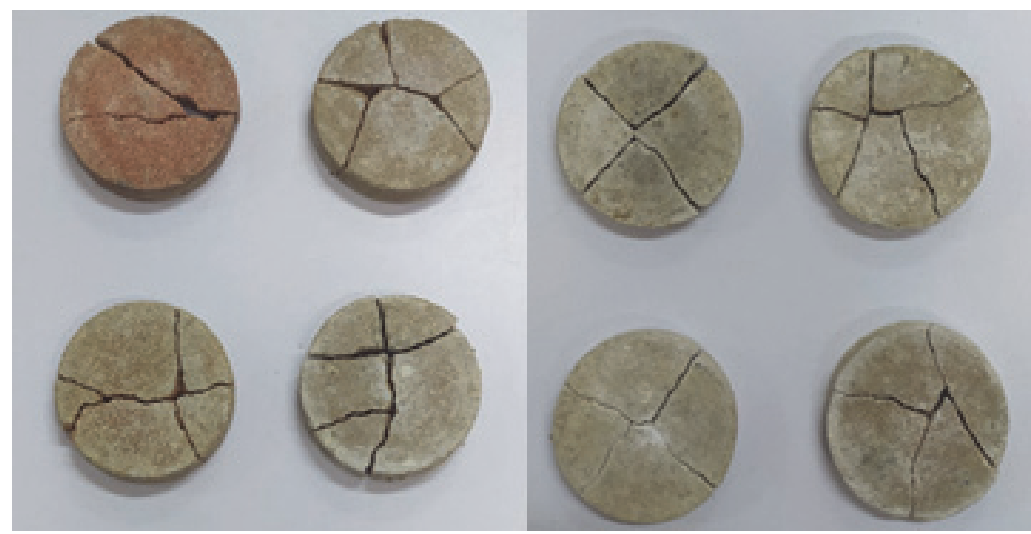

Figure 11: Representation of the cracked stones from the triaxial experiments.

\begin{tabular}{cccccccccc}
\hline StdOrdER & RunOrder & CentrerPt & Blocks & SSC $^{(-1,+1)}$ & CSVT $^{\text {FC }}(-1,+1)$ & $\begin{array}{c}\mathrm{C}^{\prime} \\
(\mathrm{kPa})\end{array}$ & $\begin{array}{c}\text { Phi' } \\
(\text { degree })\end{array}$ & $\begin{array}{c}\mathrm{E}_{50} \\
(\mathrm{kPa})\end{array}$ \\
\hline 2 & 1 & 1 & 1 & $75(-1)$ & -1 & $0.5(-1)$ & 128.49 & 38.78 & 761.78 \\
4 & 2 & 1 & 1 & $75(+1)$ & 1 & $0.5(+1)$ & 142.24 & 42.78 & 1154.22 \\
5 & 3 & 1 & 1 & $50(-1)$ & -1 & $1(-1)$ & 179.22 & 49.22 & 1727.24 \\
7 & 4 & 1 & 1 & $50(+1)$ & 1 & $1(+1)$ & 182.61 & 52.60 & 1873.45 \\
8 & 5 & 1 & 1 & $75(-1)$ & 1 & $1(-1)$ & 164.06 & 43.56 & 965.83 \\
1 & 6 & 1 & 1 & $50(+1)$ & -1 & $0.5(+1)$ & 166.09 & 47.47 & 1914.38 \\
3 & 7 & 1 & 1 & $50(-1)$ & 1 & $0.5(-1)$ & 174.00 & 52.04 & 2399.53 \\
6 & 8 & 1 & 1 & $75(+1)$ & -1 & $1(+1)$ & 154.35 & 37.49 & 828.69 \\
\hline
\end{tabular}

Table 3: The used parameters in Minitab 19.

Results and discussion of the design of experiments method (DOE)

Tab. 4 consists of the results of the unsuccessful experimental tests, which are calculated by Eqns 3-5.

$$
\begin{aligned}
& C^{\prime}=160.921+(-14.097 \times S S C)+(4.345 \times C S V T)+(-8.678 \times F C) \\
& +(0.1072 \times S S C \times C S V T)+(3.038 \times S S C \times F C) \\
& \varphi^{\prime}=54.681+(-4.840 \times S S C)+(2.252 \times C S V T)
\end{aligned}
$$




$$
\begin{aligned}
& E_{50}=1455.42+(-525.51 \times S S C)+(145.12 \times C S V T)+(-104.34 \times F C)+(-12.72 \times S S C \times C S V T) \\
& +(73.97 \times S S C \times F C)+(-74.28 \times C S V T \times F C)+(10.46 \times S S C \times C S V T \times F C)
\end{aligned}
$$

where:

$C^{\prime}$ : The effective cohesion.

$\varphi^{\prime}$ : The effective friction angle.

$E_{50}$ : Modulus of elasticity.

SSC : Soft soil Content (50\% and 75\%), takes two values; (+1) for 50\% and (-1) for $75 \%$.

CSVT : The types of CSV materials are: type 1 (20\% cement and $80 \%$ sand), type 2 (30\% cement and $70 \%$ sand). CSVT takes two values; (-1) for type one and (1) for type two.

FC : PP fiber contents $(0.5 \%$ and $1 \%)$, takes two values; $(-1)$ for $0.5 \%$ and $(+1)$ for $1 \%$.

Based on the obtained DOE results, there is a considerable similarity to the results of experiments. For instance, from Eqn. 3, the factor - 14.097 SC shows that the effective cohesion decreases with the increment of soft soil content, which accords with what has been obtained in the experimental results (Fig 6 (a)).

\begin{tabular}{ccccccc}
\hline $\mathbf{S S}^{\mathbf{C}}(\mathbf{\%})$ & $\mathbf{S}^{\mathbf{C}}(\mathbf{\%})$ & $\mathbf{C}^{\mathbf{c}}(\boldsymbol{\%})$ & $\mathbf{F}^{\mathbf{C}}(\mathbf{\%})$ & $\boldsymbol{C}^{\prime}(\mathbf{K P a})$ & $\boldsymbol{\varphi}^{\prime}(\mathbf{d e g r e e})$ & $\boldsymbol{E}_{\mathbf{5 0}}(\mathbf{k P a})$ \\
25 & 60 & 15 & 0 & 169.13 & 50.73 & 3098.92 \\
25 & 60 & 15 & 0.5 & 203.72 & 56.16 & 3067.2 \\
25 & 60 & 15 & 1 & 204.125 & 60.95 & 2626.05 \\
25 & 52.5 & 22.5 & 0 & 172.88 & 51.26 & 3713.73 \\
25 & 52.5 & 22.5 & 0.5 & 205.79 & 61.3 & 3644.8 \\
25 & 52.5 & 22.5 & 1 & 201.195 & 61.64 & 2781.45 \\
\hline
\end{tabular}

Table 4: DOE results.

\section{NUMERICAL MODELING}

A finite element analysis with PLAXIS 3D was implemented to study the behaviour of soft soil (Mila) reinforced with CSV in terms of displacements in three directions and security factors. In the first part, the previously bibliographical studies on the models of materials have been investigated for the sake of picking up the models that provide satisfying results. In the next part, the numeric results are validated by the analytic results. In the last part, the behaviour of soils reinforced by CSV under embankment will be investigated.

The first steps in numerical study begin with the materials' selection models for soils (soft soil, sand and clay) and the CSV materials (mixed of soil-sand-cement). Various works have been conducted to select the best suitable model of soft soil. For instance, in [37] the Mohr column (MC) model is not used for the modelling of soft soil in this research due to the unsatisfying results, for instance, the strong non-linear stiffness which depends on the stress level. For the remaining models in [38], the authors have compared the pressure behaviour of the PLAXIS soft soil model (SSM) to the Oedometer test results shown in Fig. 12. Furthermore, the authors have compared the Harding soil model (HSM) for soft soil to Oedometer experimental results shown in Fig. 13. Accordingly, it is found that the SSM has accurately given the same results as the experimental tests. In our study, we have adopted the SSM model for soft soil as in [24,39-41]. Concerning the sands, HSM is applied. For instance, in $[24,42,43]$, the authors have used HSM to estimate the behaviours in soil which lacks high compressibility. For the model of CSV materials in [44-49], the constitutive model for the fiber-sand composite is calibrated against the results of drained triaxial compression and extension tests; the simulations are quite close to the experimental results. For this exact reason, we have used the MC model for CSV materials.

The used parameters in this study are obtained from a mixture of experimental tests and previous works. Concerning the results obtained from former works; in [50], the authors have developed a stress-dependent stiffness according to a powerlaw $m$ (input parameter in SSM), for sands and silts, $m$ is suggested to take part in the range of $0.5<m<1$. In [51], it is 
commonly recommended that both consolidated clays and soft soil take $m=1$, and $\theta=0$ ( $\theta$ is the dilatacy's angle). Additionally, the earth pressure's influence in the performance of a stone column can be labelled as $K_{0}$. In [52], a study has been done using numerical and analytical methods to extract the $K_{0}$ value. The parameters of CSV materials are shown in (Tabs. 2 and 4), and the parameters of the used materials are shown in Tab. 5.

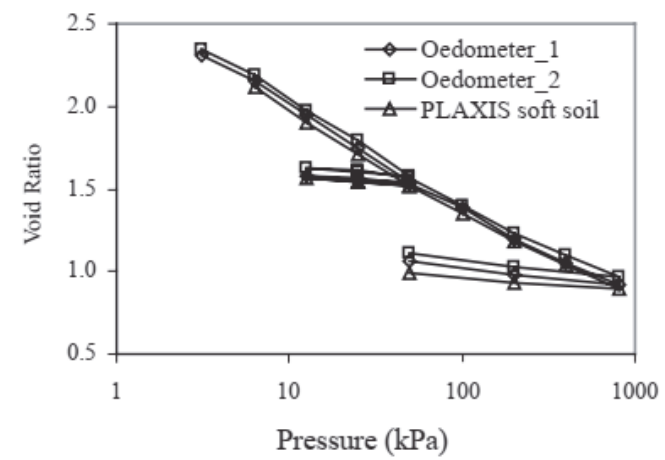

Figure 12: Comparison of SSM to Oedometer results. [38]

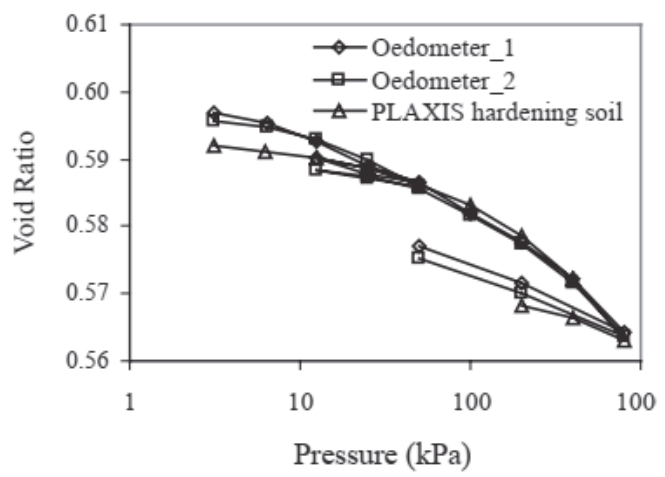

Figure 13: Comparison of HSM to Oedometer results. [38]

\begin{tabular}{|c|c|c|c|c|}
\hline Parameter & Embankment & Sand & Clay & Soft soil \\
\hline Material model & HSM & HSM & SSM & SSM \\
\hline Drainage type & Drained & Drained & Undrained (A) & Undrained (A) \\
\hline$\gamma_{\text {unsat }}\left(\mathrm{kN} / \mathrm{m}^{3}\right)$ & 16 & 17 & 8 & 17.26 \\
\hline$\gamma_{\text {sat }}\left(\mathrm{kN} / \mathrm{m}^{3}\right)$ & 19 & 20 & 12 & 20.56 \\
\hline $\boldsymbol{e}_{\text {init }}$ & 0.5 & 0.88 & 2 & 0.98 \\
\hline $\boldsymbol{E}_{50}^{\boldsymbol{r e f}}\left(\mathrm{kN} / \mathrm{m}^{3}\right)$ & $2.510^{4}$ & $3.510^{4}$ & - & - \\
\hline $\boldsymbol{E}_{\text {oed }}^{\boldsymbol{r e f}}\left(\mathrm{kN} / \mathrm{m}^{3}\right)$ & $2.510^{4}$ & $3.510^{4}$ & - & - \\
\hline $\boldsymbol{E}_{\boldsymbol{u}}^{\boldsymbol{r e f}}\left(\mathrm{kN} / \mathrm{m}^{3}\right)$ & $7.510^{4}$ & $1.0510^{5}$ & - & - \\
\hline$m$ & 0.5 & 0.5 & - & - \\
\hline$\lambda^{*}$ & - & - & 0.15 & 0.042 \\
\hline$k^{*}$ & - & - & 0.03 & 0.018 \\
\hline$C^{\prime}\left(\mathrm{kN} / \mathrm{m}^{3}\right)$ & 1 & 0 & 2 & 20.17 \\
\hline$\varphi^{\prime} \circ$ & $30^{\circ}$ & $33^{\circ}$ & $23^{\circ}$ & $13.29^{\circ}$ \\
\hline$\psi^{\circ}$ & $0^{\circ}$ & $3 \circ$ & $0^{\circ}$ & $0^{\circ}$ \\
\hline
\end{tabular}

Table 5: Parameters of materials used in PLAXIS model.

The conception of the model depicts crossroad-section with a 16 -meter-wide embankment. The slopes are $1 / 3$ in inclination. One-half of the problem is simulated since the problem is symmetrical (in this case, the right half is chosen). A representative section of $2 \mathrm{~m}$ in direction $\mathrm{y}$, as shown in Fig. 15. The embankment's soil is sand and the subsoils consist of $12 \mathrm{~m}$ of soils; the first $3 \mathrm{~m}$ of sand followed by $6 \mathrm{~m}$ of soft soil and the lower part is $9 \mathrm{~m}$ as clay. One meter underneath the original earth's surface is the phreatic level. The design of the targeted model is illustrated in Figs. 14. As for the soil reinforced with CSV, 20 columns were used; each column consists of $20 \mathrm{~cm}$ in diameters and $10 \mathrm{~m}$ in length, separated from each other by $1 \mathrm{~m}$. The design of the model which is reinforced by CSV is depicted in Fig. 16.

In [51], the design of an embankment in which the above-mentioned mechanism is thoroughly examined. A consolidation analysis and the determination of a safety factor using a safety analysis (phi/c-reduction) are two new calculations alternatives offered in the analysis. In the calculation phase, the embankment is built up in two stages. A 30-days consolidation time is inserted after the first building phase to allow excess pore pressures to dissipate. Starting with the second construction phase, a consolidation period is implemented from which final settlements can be calculated. Apart from the first phase. Five calculation phases must be defined in the numeric model as follows: 
- The first phase is dedicated to activating the first part of the embankment with/without CSV.

- The second phase includes a consolidation analysis with an end-of-period time.

- The third phase is for activating the second part of the embankment.

- The fourth phase is for a consolidation analysis to minimum pore pressure.

- The fifth phase is to determine the security factor.

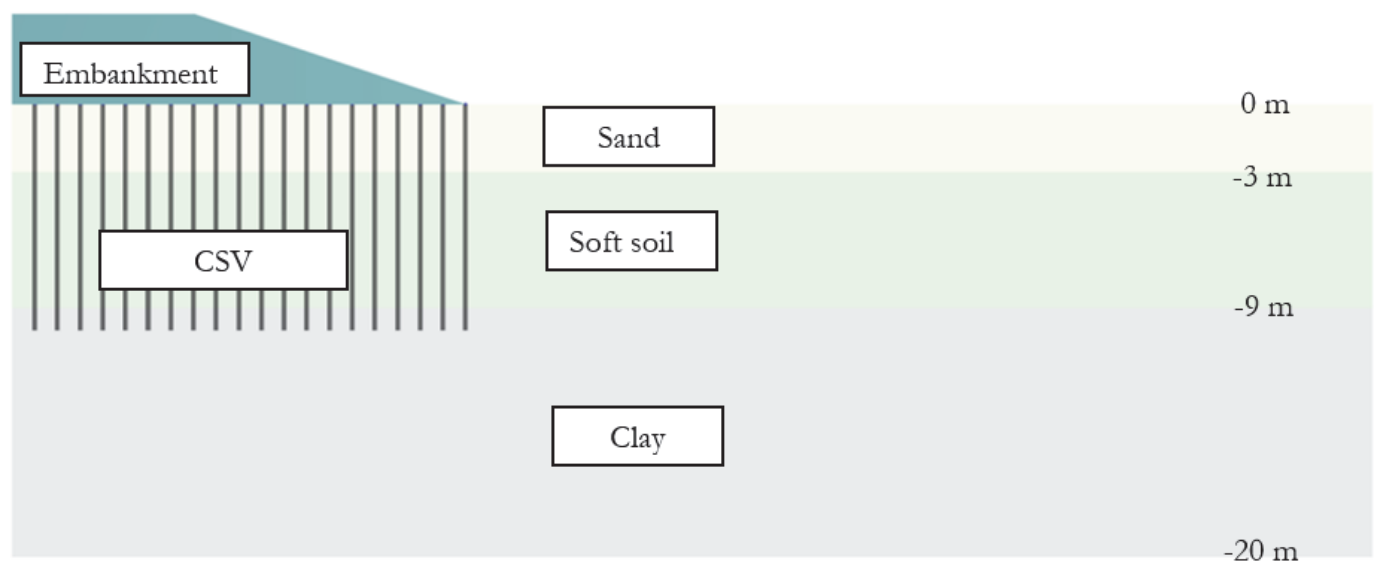

Figure 14: Embankment building over soils reinforced by CSV 2D.

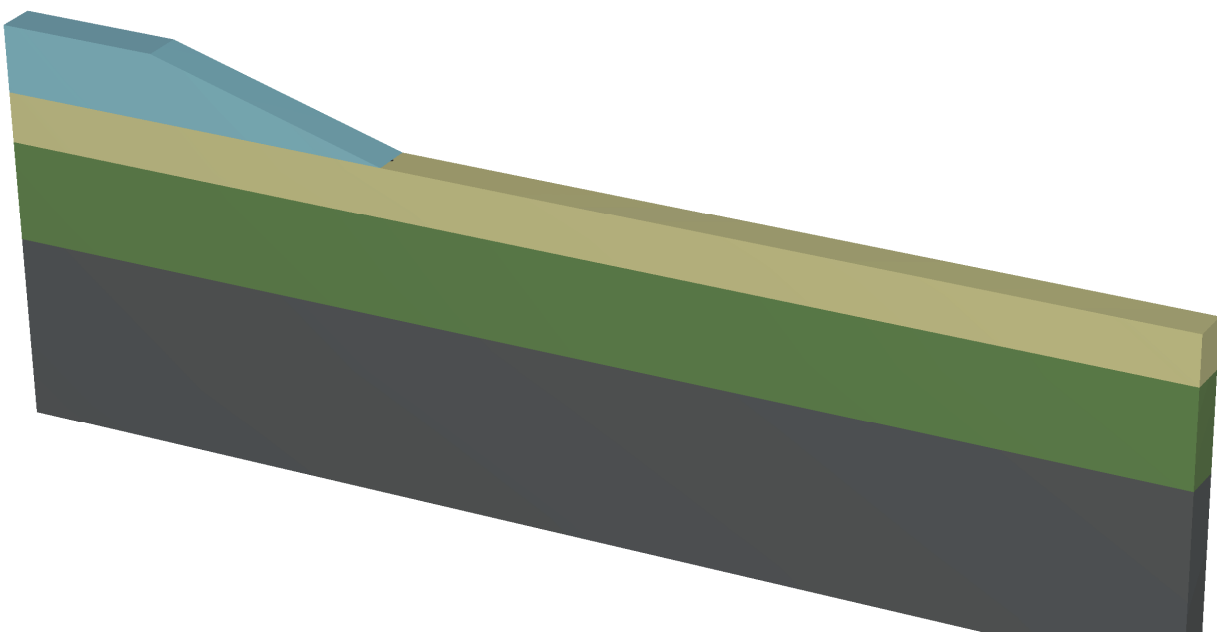

Figure 15: Embankment building over soils without CSV.

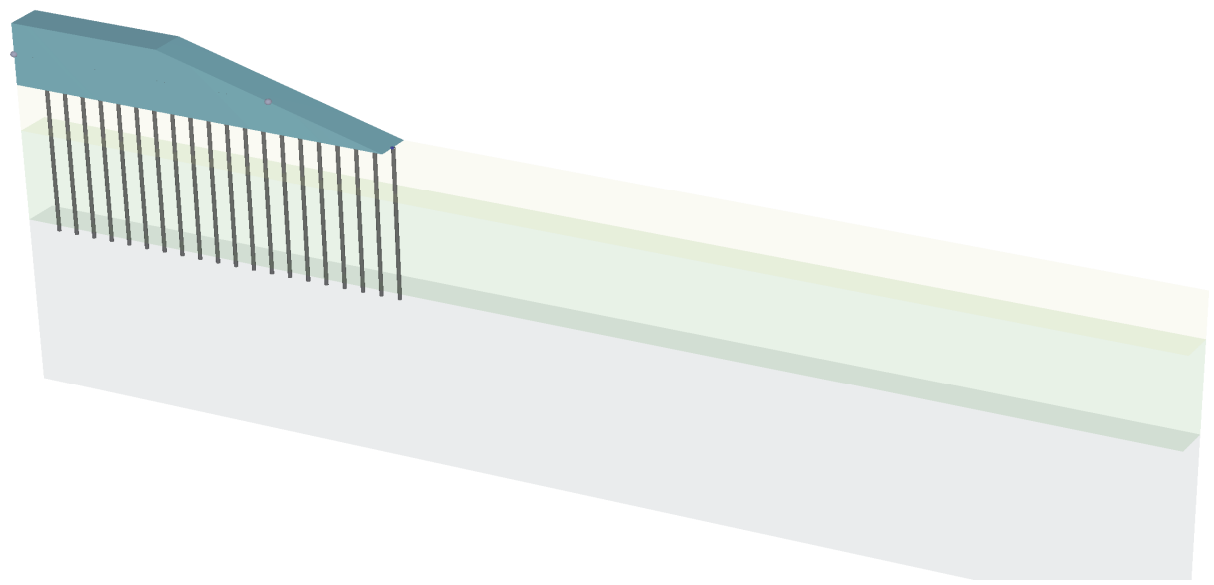

Figure 16: Embankment building over soils reinforced by CSV. 
In the description of the boundary conditions, there are two types of boundary conditions in PLAXIS 3D; Boundary conditions concerning groundwater flow and boundary conditions for displacement which use default fixities as follows in Fig 17. $X_{\min }=$ horizontally fixed, $X_{\max }=$ horizontally fixed, $Y_{\min }=$ horizontally fixed, $Y_{\max }=$ horizontally fixed, $Z_{\min }=$ horizontally fixed, and $Z_{\max }=$ horizontally fixed. For groundwater flow's boundary conditions as the vertically upward (Zmin and Zmax and Xmax are open), swelling displacements are intended to be assessed as shown in Fig. 17.

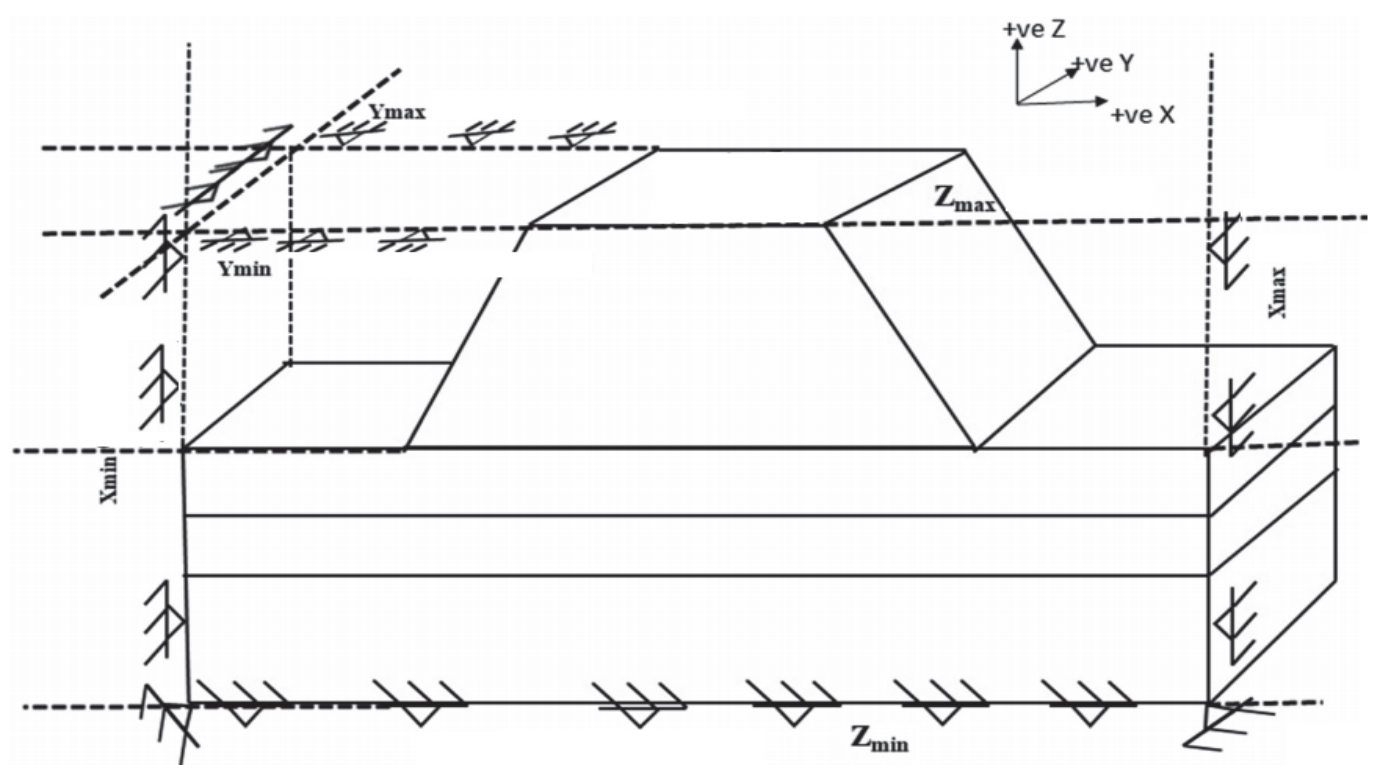

Figure 17: the boundary condition. [53].

In this part, the results of the numerical model were validated by the analytic results. The consolidation settlements consist of two categories; primary consolidation settlements and secondary consolidation settlements. The former takes a long time until all excess pore pressure is dissipated. The latter consolidation, however, is a viscous behaviour of the soil-water system causing slow rate compression [54]. The primary settlements are calculated using the works of Terzaghi as is shown in Tab. 6. It is noticed that the primary consolidation has a higher value than the secondary consolidation. For this reason, we exclusively calculate the value of primary consolidation which itself is used for the sake of validating the numerical results. We compare the value of total settlements calculated by the analytic method $(0,4517 \mathrm{~m})$ which is shown in tab. 7 , and the settlements from Plaxis $(0,5112 \mathrm{~m})$ as it is shown in Fig. 18, good accordance has been found. The characteristics of soils used for the analytic calculation of total settlements are explained in the experimental section. One meter underneath the original earth's surface is the phreatic level.

\begin{tabular}{cc}
\hline Stress history & Primary consolidation settlement \\
$\sigma_{i}^{\prime}+\Delta \sigma \prec \sigma_{p}^{\prime}$ & $p=\left(C_{s} /\left(1+e_{0}\right)\right) \cdot H \cdot \log \left(\left(\sigma_{i}^{\prime}+\Delta \sigma\right) / \sigma_{i}^{\prime}\right)$ \\
$\sigma_{i}^{\prime}+\Delta \sigma \prec \sigma_{p}^{\prime} \prec \sigma_{i}^{\prime}+\Delta \sigma$ & $p=H \cdot\left[\left(\left(C_{S} /\left(1+e_{0}\right)\right) \cdot \log \left(\sigma_{p}^{\prime} / \sigma_{i}^{\prime}\right)\right)+\left(\left(C_{c} /\left(1+e_{0}\right) \log \left(\left(\sigma_{i}^{\prime}+\Delta \sigma\right) / \sigma_{p}^{\prime}\right)\right)\right]\right.$ \\
$\sigma_{p}^{\prime} \prec \sigma_{i}^{\prime}$ & $p=\left(C_{c} /\left(1+e_{0}\right)\right) \cdot H \cdot \log \left(\left(\sigma_{i}^{\prime}+\Delta \sigma\right) / \sigma_{i}^{\prime}\right)$ \\
\hline
\end{tabular}

Table 6: Expressions for primary consolidation settlement with stress history [55].

$\Delta \sigma:$ Added pressure.

$\sigma_{i}^{\prime}$ : Average effective vertical stress on the clay layer. 
$\sigma_{p}^{\prime}$ : Preconsolidation pressure.

$p$ : Primary consolidation settlement.

$C_{r}$ : Swelling index.

$C_{c}:$ Compression index.

$e_{0}$ : Void ratio of the clay before the application of load.

$H$ : Thickness of the clay layer.

\begin{tabular}{ccccc}
\hline The soils Layers & Sand & Soft soil & Clay & Total \\
Settlement $(\mathrm{m})$ & 0.0941 & 0.1784 & 0.1795 & 0.4517 \\
\hline
\end{tabular}

Table 7: the settlements of soils layer under the embankment with the analytic method.

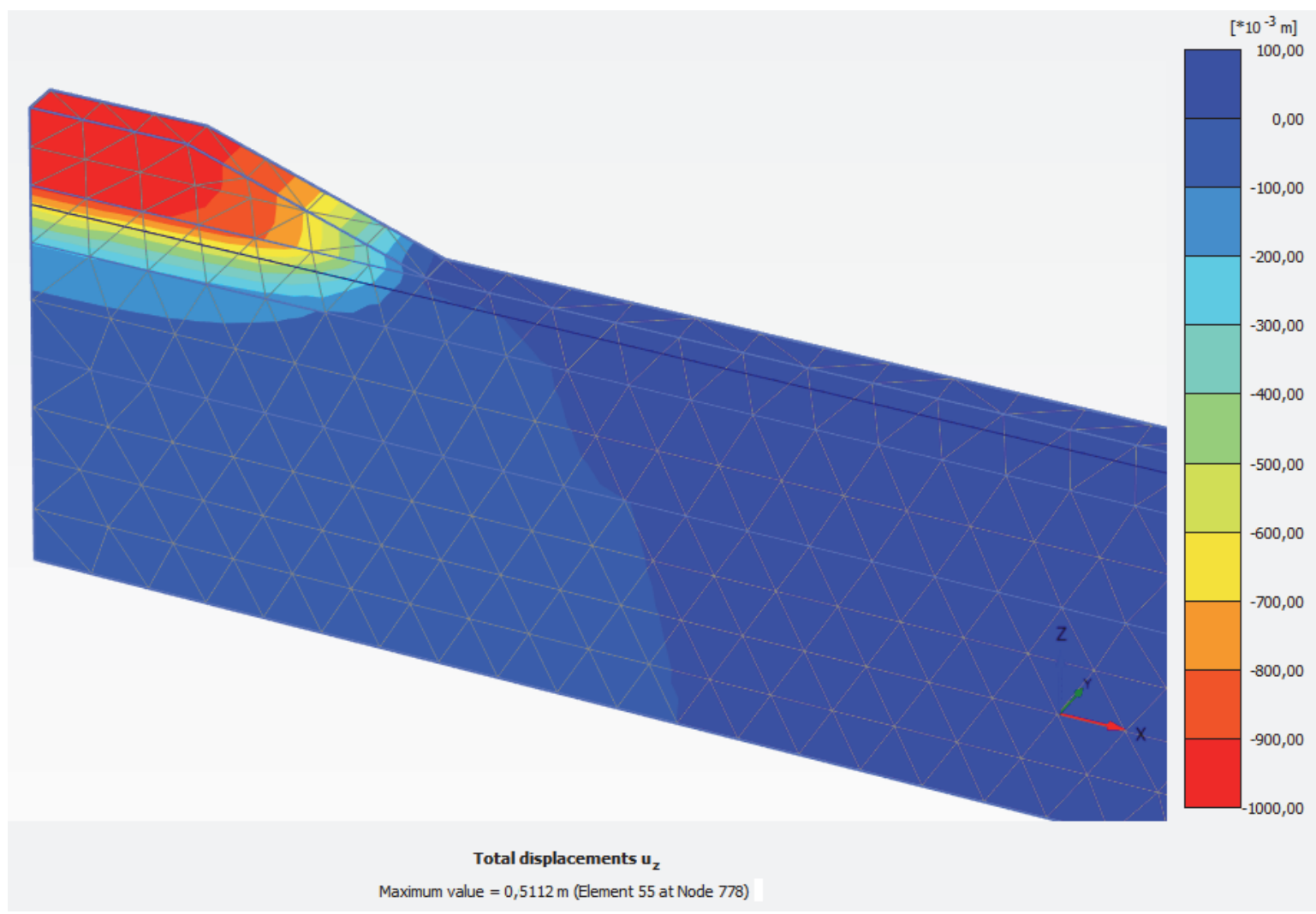

Figure 18: The settlement $(\mathrm{Uz})$ of the model without CSV.

\section{Results of the numerical modelling and ciscussion}

The numerical results, in Figs. 19-22 depicts the results of the displacements in three directions: total displacement and factor of security are demonstrated. Figs. 23-28 show the distribution of displacement in the numerical model with/without CSV. The numerical results are summarised in Tab. 8.

To investigate the behaviour of the soils reinforced by CSV under the embankment, we compared the displacements between the numerical model with CSV to the numerical models without CSV (Tab. 7). From this comparison, it is remarked that the displacements in three directions as well as the total displacement are diminished, namely $((\mathrm{Ux}$ and $\mathrm{Uy}$ by $(70 \%$ $80 \%)$, Uz by (150\%-160\%), Ut by (90\%-100\%)). Moreover, the security factor increases by $(85 \%-100 \%)$ for the numerical 
model reinforced by CSV. The source of the obtained results is the used CSV, which transfers the applied load (embankment) down to the bearing stratum (clay). The same results are found by many researchers [56,57].

From the Figs. 19-22 and Tab.8. The effect of the varied combination of CSV materials (with/without PP fiber) in the numerical results is investigated as follows:

- The displacements in direction X, Y, Z and total displacement are enhanced by increasing the content of soft soil in CSV materials. The adding of PP fiber represents a relatively lower effect on the results. Type 1 of CSV materials is much better.

- The security factor is enhanced by decreasing the content of soft soil in CSV materials. The added PP fiber enhances the obtained results. Type 2 of CSV materials display better results in all varied combinations.

Studying the effect of CSV in the distribution of displacements in the numerical model, from Figs. 24 and 27 depict the displacement's distribution in the X direction of the numerical models with/without CSV, respectively. Comparably, it is shown that the displacements were distributed throughout the adopted numerical model, knowing that it was concentrated in a specific location. In Figs. 25 and 28, the reinforcement by CSV has a low effect on the displacements of the Y direction. In Figs. 24 and 27, it is noteworthy to say that the displacements in the Z direction - located in the embankment - remarkably decreases until it fades because it was built upon reinforced soils.

\begin{tabular}{cccccc}
\hline CSV materials & $\mathbf{U x}(\mathbf{c m})$ & $\mathbf{U y}(\mathbf{c m})$ & $\mathbf{U z}(\mathbf{c m})$ & $\mathbf{U t}(\mathbf{c m})$ & $\mathbf{F c}$ \\
\hline Soft soil (without CSV) & 30.17 & 1.098 & 51.12 & 97.8 & 0.9 \\
75.T1.F0 & 6.738 & 0.1221 & 2.342 & 6.799 & 1.77 \\
75.T1.F0,5 & 6.78 & 0.1601 & 2.34 & 6.842 & 1.813 \\
75.T1.F1 & 6.758 & 0.1344 & 2.356 & 6.821 & 1.842 \\
75.T2.F0 & 6.717 & 0.1093 & 2.327 & 6.775 & 1.78 \\
75.T2.F0,5 & 6.719 & 0.1106 & 2.326 & 6.778 & 1.854 \\
75.T2.F1 & 6.75 & 0.1301 & 2.35 & 6.813 & 1.847 \\
50.T1.F0 & 6.736 & 0.1203 & 2.34 & 6.796 & 1.706 \\
50.T1.F0,5 & 6.78 & 0.1601 & 2.34 & 6.842 & 1.762 \\
50.T1.F1 & 6.792 & 0.1693 & 2.348 & 6.855 & 1.747 \\
50.T2.F0 & 6.711 & 0.1059 & 2.322 & 6.768 & 1.757 \\
50.T2.F0,5 & 6.755 & 0.1416 & 2.321 & 6.814 & 1.78 \\
50.T2.F1 & 6.783 & 0.1619 & 2.342 & 6.845 & 1.783 \\
25.T1.F0 & 5.87 & 0.2576 & 2.923 & 5.943 & 1.606 \\
25.T1.F0,5 & 6.567 & 0.2535 & 2.392 & 6.646 & 1.655 \\
25.T1.F1 & 6.845 & 0.2511 & 2.335 & 6.911 & 1.677 \\
25.T2.F0 & 6.806 & 0.183 & 2.358 & 6.871 & 1.641 \\
25.T2.F0,5 & 6.831 & 0.2116 & 2.376 & 6.9 & 1.695 \\
25.T2.F1 & 6.849 & 0.233 & 2.387 & 6.92 & 1.71 \\
\hline
\end{tabular}

Table 8: The numeric results. 


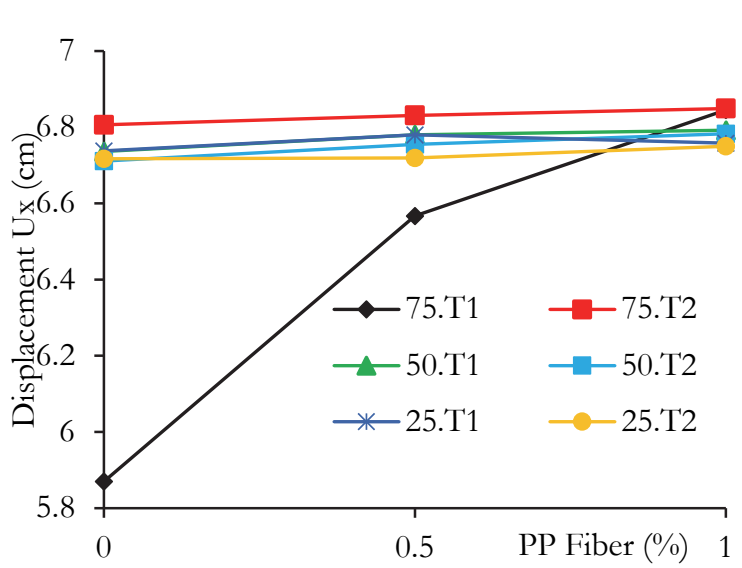

Figure 19: Ux of model numeric reinforced by CSV.

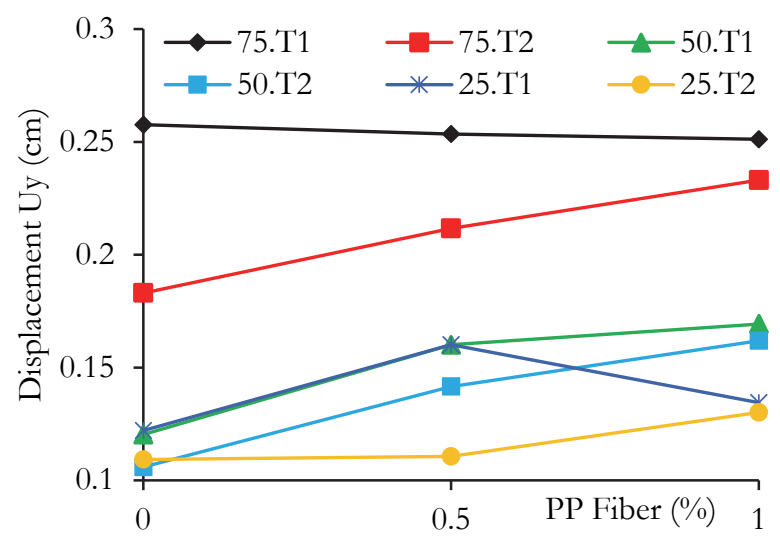

Figure 20: Uy of model numeric reinforced by CSV.

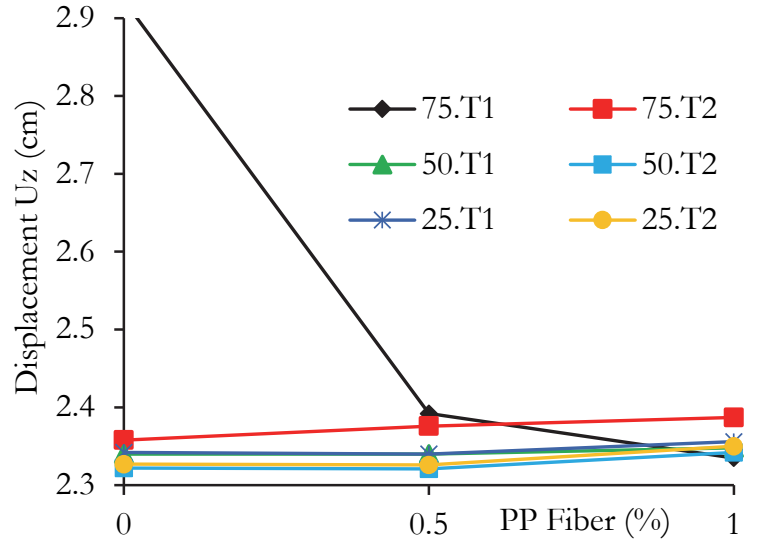

Figure 21: Uy of model numeric reinforced by CSV.

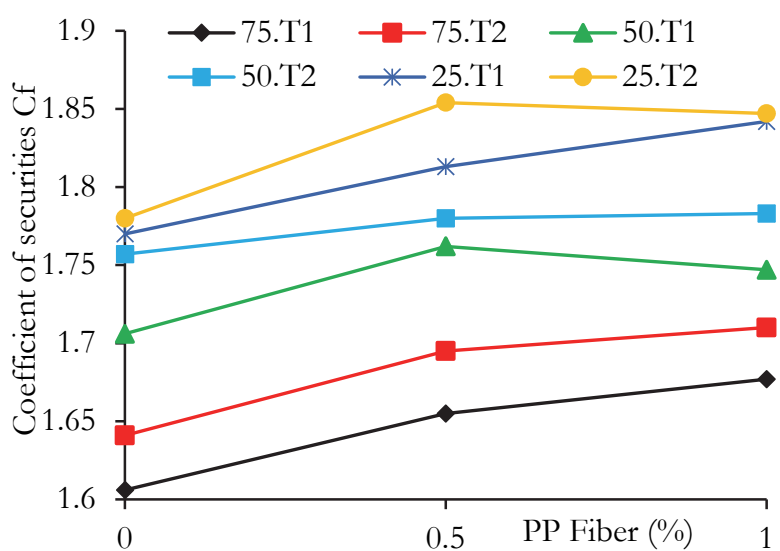

Figure 22: $\mathrm{C}_{\mathrm{f}}$ of model numeric reinforced by CSV.

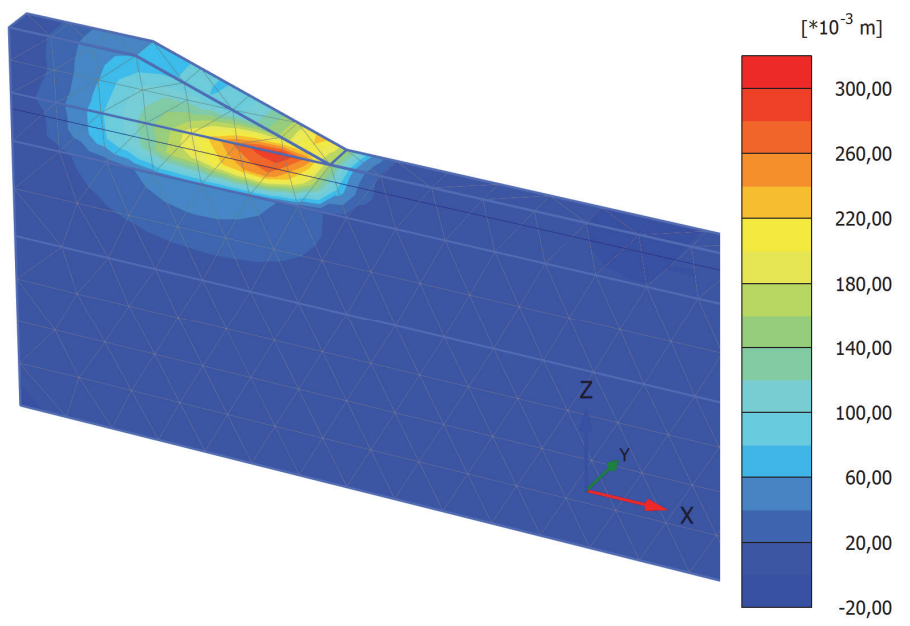

Figure 23: The distribution of displacements (direction X), the soils under embankment without reinforcement. 


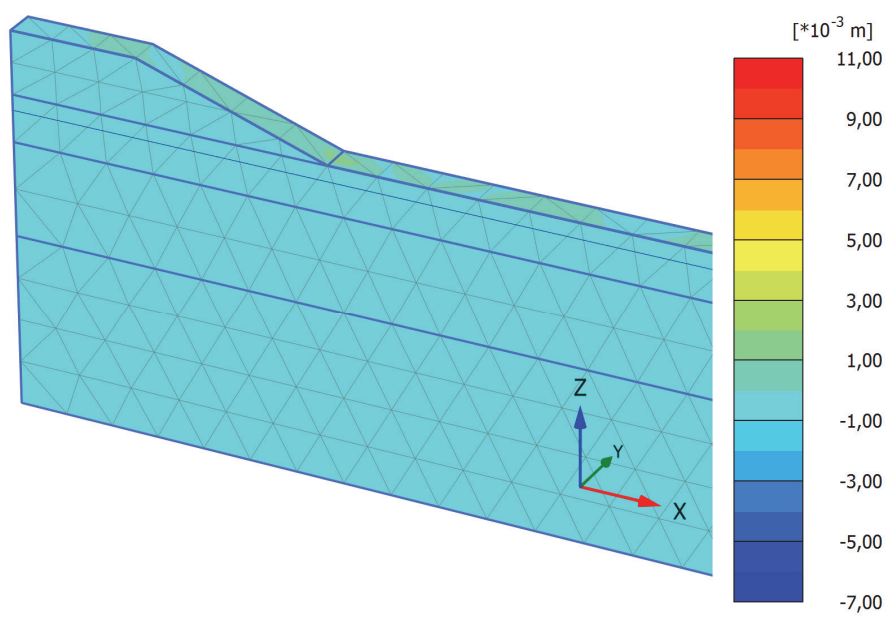

Figure 24: The distribution of displacements (direction Y), the soils under embankment without reinforcement.

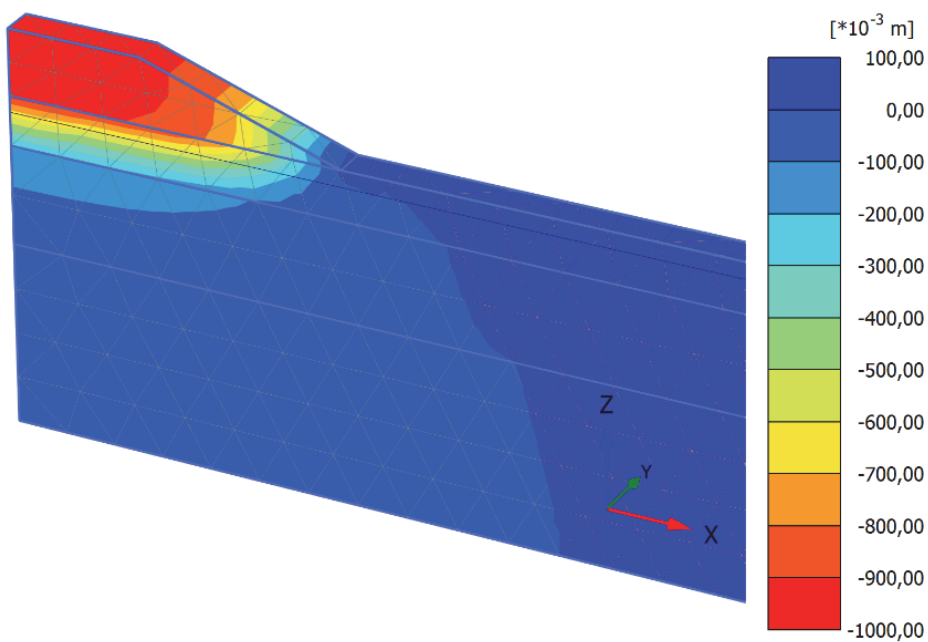

Figure 25: The distribution of displacements (direction Z), the soils under embankment without reinforcement.

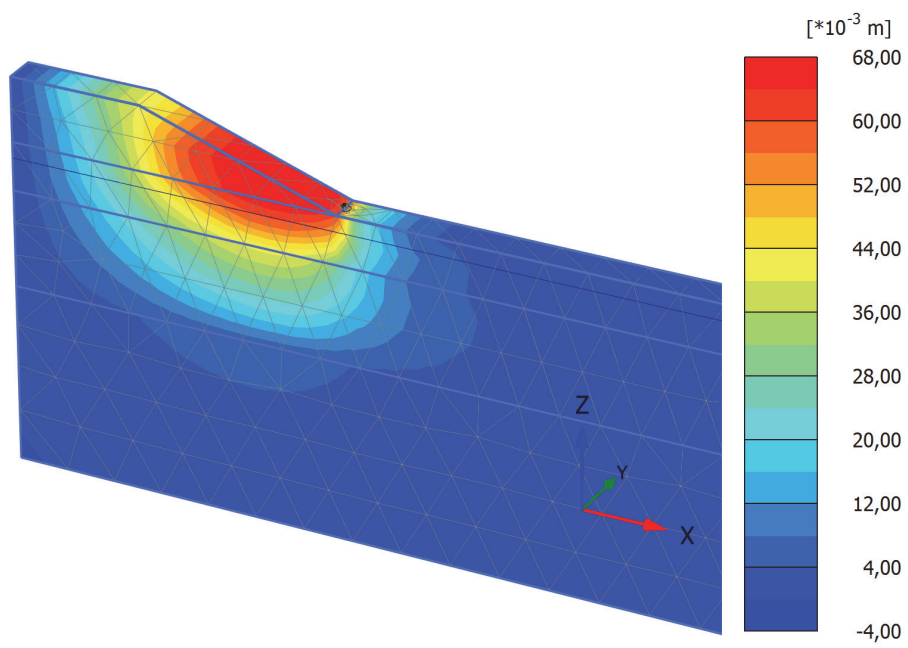

Figure 26: The distribution of displacements (direction X), the soils under embankment reinforced by CSV. 


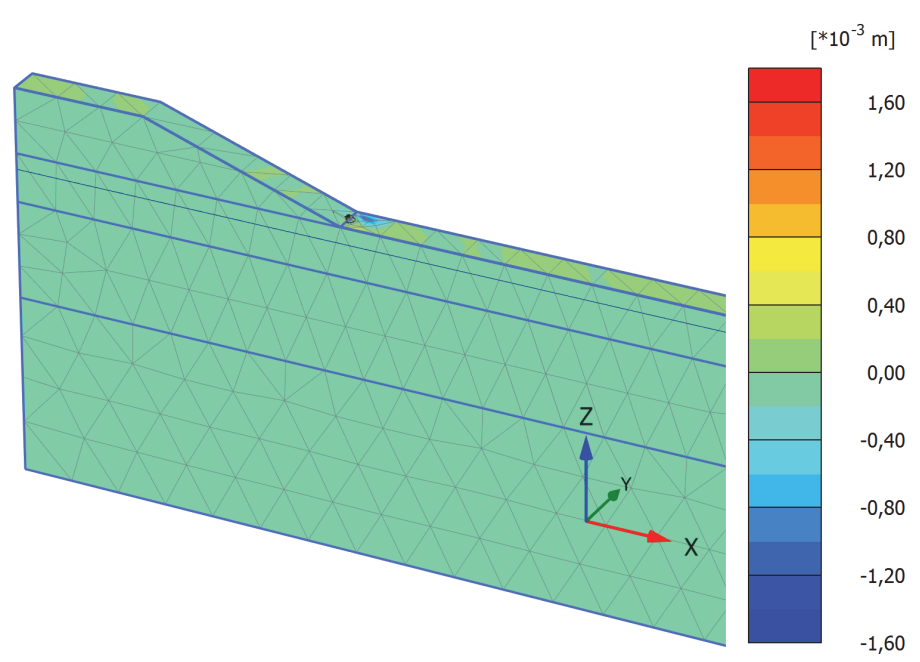

Figure 27: The distribution of displacements (direction Y), the soils under embankment reinforced with CSV.

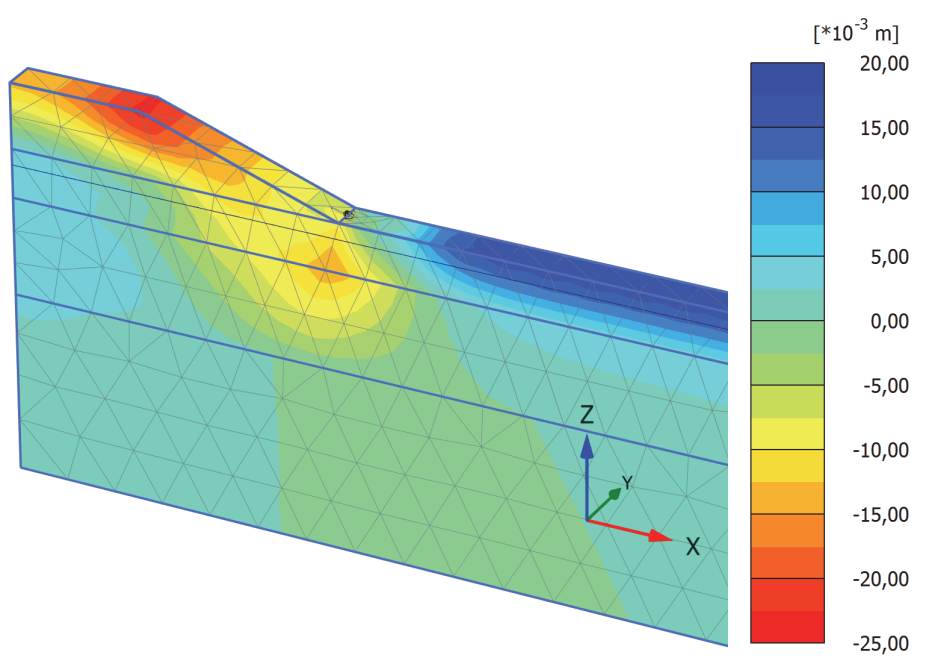

Figure 28: The distribution of displacements (direction Z), the soils under embankment reinforced with CSV.

\section{CONCLUSION}

$\mathrm{n}$ the present paper, an experimental and numerical study is adopted to study the effectiveness of CSV for the sake of reinforcing the soft soil of Mila (Algeria).

In the first part, from the triaxial tests and analysis using the design of experiments method (DOE), it is concluded :

- The results of the reinforced soft soil with CSV outperforms the non-reinforced soft soil.

- Reinforcing soft soil by CSV remarkably increases deviatoric stress (+500\%), effective cohesion (+259\%), fraction angle $(+153 \%)$, modulus of elasticity $\mathrm{E}_{50}(+1000 \%)$; and a decrease in axial strain by $(-83 \%)$.

- The added PP fiber in CSV materials was of a greater magnitude.

- The decrease of soft soil quantity in materials of CSV with/without Polypropylene fiber paves the way to an increase in peak stress, and the behaviour is similar to perfect plastic materials.

- The less soft soil in CSV materials is associated with; improvement in the deviatoric stress, the axial strain, the effective cohesion, the effective friction angle, and the modulus of elasticity.

- Adding Polypropylene fiber with a decreasing quantity of the soft soil in materials of CSV has a remarkable effect; higher and lower values of the elasticity modulus are observed. 
- The obtained equations from the analysis with the design of experiments method (DOE) have enabled the calculation of the parameters of the materials of CSV which were not doable through experimental tests, and that can be performed within a short time. Most importantly, it is inexpensive.

For the last part, the numerical study with PLAXIS 3D is developed to investigate the behaviour of soils reinforced by CSV under the embankment. The results can be summarised as follows:

- The building of the embankment over soils, which are reinforced by CSV, shows an improvement in the level of displacements in three directions ( $\mathrm{x}, \mathrm{y}$, and $\mathrm{z}$ ), in the total displacement, and the security factor for the soils reinforced by CSV. Indeed, the varied combination of CSV materials (with/without PP fiber) provides a relatively lower effect on the numerical results.

\section{Data Availability}

The data used in the experimental results as well as in the geotechnical study of soft soil (Mila city) were performed by two governmental laboratories and through the developed numerical model, which supports the findings in this study are available by the corresponding author upon request.

\section{PERSPECTIVES}

O ince the columns of soil-sand-cement have not been previously studied, a wide range of potential future works can be established. Experimentally, the effect of curing time on the behaviour of the characteristics of the CSV materials can be studied. For the numerical study, the effect of columns' dimension, as well as the distance between the columns on the displacement and the factor of security of the numeric models, can be investigated.

\section{AbBreviations}

$\mathrm{T}$ he abbreviations used in this paper are as follow: Soft soil content (SSC).

Sand content (SC).

Cement content (CC).

Polypropylene (PP).

The columns of mixed soil-sand-cement (CSV).

Mixed of soil, sand and cement (CSV materials).

The design of experiments (DOE).

Consolidated drained (CD).

Cell pressure (CP).

The displacements in direction $\mathrm{x}, \mathrm{y}$ and $\mathrm{z}(\mathrm{Ux}),(\mathrm{Uy})$ and $(\mathrm{Uz})$.

The total displacement $(\mathrm{Ut})$.

The factor of security $(\mathrm{Fc})$.

25.T1.F0;0,5;1 means; $25 \%$ soft soil content (25), ratio 1 or type 1 (T1), percentage of PP fibers $0 \%, 0.5 \%, 1 \%$ (F0;0,5;1). Soft Soil Model (SSM).

Harding Soil Model (HSM).

Mohr Coulomb Model (MC).

7a, 8a, 9a and 10a (7a-10a).

Concerning the symbols (nomenclature); they are explained in detail under each equation.

\section{REFERENCES}

[1] Salem, T., Maaly, H., Abdelbaset, A. (2021). Analysis of Above-Ground Steel Storage Tanks Resting Over Piles or Stone Columns, Frat. Ed Integrità Strutt., 15(57), pp. 40-49. 
[2] Pandya, P., Kamdar, B. (2021).An Experimental Investigation of Properties of Black Cotton Soil Treated with Copper Slag and Groundnut Shell Powder. Proceedings of the Indian Geotechnical Conference 2019, Springer, pp. 815-823.

[3] Wang, W., Luo, Q., Yuan, B., Chen, X. (2020). An Investigation of Time-Dependent Deformation Characteristics of Soft Dredger Fill, Adv. Civ. Eng.

[4] Kassou, F., Benbouziyane, J., Ghafiri, A., Sabihi, A. (2021). A New Approach to Analyse the Consolidation of Soft Soils Improved by Vertical Drains and Submitted to Progressive Loading, KSCE J. Civ. Eng., 25(1), pp. 51-9.

[5] Guoxing, C., Su, C., Xi, Z., Xiuli, D., Chengzhi, Q.I., Zhihua, W. (2015). Shaking-table tests and numerical simulations on a subway structure in soft soil, Soil Dyn. Earthq. Eng., 76, pp. 13-28.

[6] Zaei, M.E., Rao, K.S. (2017). Evaluating the effect of strong earthquake on slope instability, Procedia Eng., 173, pp. 1771-1778.

[7] (N.d.). 4.9 Magnitude Earthquake in Mila Province, Algeria. Available at: https://gulf-labour.com/earthquake-milaalgeria/. [accessed June 29, 2021].

[8] Kempfert, H.G., Gebreselassie, B. (2006). Excavations and foundations in soft soils, part 07, pp. $481-484$.

[9] Scheller, P.O., Reitmeier, W. (2001).Combined soil stabilization with vertical columns (CSV): a new method to improve soft soils. Soft Ground Technology, pp. 123-155.

[10]Jamsawang, P., Suansomjeen, T., Sukontasukkul, P., Jongpradist, P., Bergado, D.T. (2018). Comparative flexural performance of compacted cement-fiber-sand, Geotext. Geomembranes, 46(4), pp. 414-25, DOI: $10.1016 /$ j.geotexmem.2018.03.008.

[11] Ng, Y.C.H., Xiao, H., Armediaz, Y., Pan, Y., Lee, F.H. (2020). Effect of short fibre reinforcement on the yielding behaviour of cement-admixed clay, Soils Found., 60(2), pp. 439-453, DOI: 10.1016/j.sandf.2020.03.009.

[12] Mujah, D., Shahin, M.A., Cheng, L., Karrech, A. (2021). Experimental and Analytical Study on Geomechanical Behavior of Biocemented Sand, Int. J. Geomech., 21(8), pp. 4021126.

[13] ShahriarKian, M., Kabiri, S., Bayat, M. (2021). Utilization of zeolite to improve the behavior of cement-stabilized soil, Int. J. Geosynth. Gr. Eng., 7(2), pp. 1-11.

[14] Alnmr, A., Ray, R.P. (2021). Review of the effect of sand on the behavior of expansive clayey soils, Acta Tech. Jaurinensis, pp.1-31. DOI: 10.14513/actatechjaur.00611.

[15] Khoso, A.R., Fahim, M., Memon, J., Akhund, M.A. (n.d.). (2017). Experimental Analysis on Tensile Behaviour of ECC using Polypropylene Fiber, $9^{\text {th }}$ Conference International Civil Engineering Congress, Pakistan.

[16] Vafaei, D., Hassanli, R., Ma, X., Duan, J., Zhuge, Y. (2021). Sorptivity and mechanical properties of fiber-reinforced concrete made with seawater and dredged sea-sand, Constr. Build. Mater., 270, pp. 121436.

[17] Marak, B.K., Borthakur, N. (2021).Behaviour of Square Footing on Cement Modified Fibre Reinforced Sand Layer Underlain by Soft Clayey Soil. Proceedings of the Indian Geotechnical Conference 2019, Springer, pp. 1-11.

[18] Omo, Y., Kalita, A. (2021). Energy Absorption Properties of Fly Ash-Cement Treated Soil Reinforced with Bagasse and Glass Fibre Wastes Based on UU Triaxial Tests, Adv. Sustain. Constr. Mater. Sel. Proc. ASCM 2020, 124, pp. 277.

[19] Moslemi, A., Tabarsa, A., Mousavi, S.Y., Aryaie Monfared, M.H. (2020). Use of Taguchi Method to Evaluate the Hydraulic Conductivity of Lignocellulosic Fibers-Reinforced Soil, AUT Journal of Civil Engineering, DOI: 10.22060/AJCE.2020.18163.5660.

[20] Nwonu, D.C., Mama, C.N. (2021). Delineating the Aptness of Improved Geomaterial Strength for Ground Improvement Through Microstructure and Cluster Analysis, Indian Geotech. J., pp. 1-15.

[21] Bak, H.M., Halabian, A.M., Hashemolhosseini, H., Rowshanzamir, M. (2021). Axial response and material efficiency of tapered helical piles, J. Rock Mech. Geotech. Eng., 13(1), pp. 176-187.

[22] Dounane, N., Trouzine, H. (2020). Integrated approach of ANN and Taguchi algorithms for soils swelling estimation, International Journal of Sustainable Building Technology and Urban Development, pp. 244-257, DOI: https://doi.org/10.22712/susb.20200019,.

[23] Azijul Islam, M., Basit Zaman, M.N., Fahim Badhon, F., Bhandari, P., Hossain, M.S. (n.d.).Numerical Modeling of Recycled Plastic Pin Reinforced Embankment over Soft Soils. IFCEE 2021, pp. 541-550.

[24] Ali, A.B., Ansary, M.A. (2021). Numerical Analysis of Staged Construction of an Embankment on Soft Soil. University of Engineering and technology. Bangladesh, Master thesis, part 4, pp. 106-177.

DOI: http://lib.buet.ac.bd:8080/xmlui/handle/123456789/5740

[25] Nguyen, T.A., Nguyen, T.N. (2020). Study on Stress Distribution in Soft Ground Consolidated with Deep Cement Mixing Columns under Road Embankment.

[26] ASTM. (2011). Method for consolidated drained triaxial compression test for soils, D 7181, Annu. B. Stand.

[27] Lade, P. V. (2016). Triaxial Testing of Soils, pp. 321-370.

[28] Shen, Y., Tang, Y., Yin, J., Li, M., Wen, T. (2021). An experimental investigation on strength characteristics of fiber- 
reinforced clayey soil treated with lime or cement, Constr. Build. Mater., 294, pp. 123537.

[29] Ho, T.-O., Chen, W.-B., Yin, J.-H., Wu, P.-C., Tsang, D.C.W. (2021). Stress-Strain behaviour of Cement-Stabilized Hong Kong marine deposits, Constr. Build. Mater., 274, pp. 122103.

[30] Xin, C., Ze, Z., Dongqing, L.I. (2020). Study on Strength Characteristics and Damage Constitutive Model of Cemented Soil, Journal of Hunan University natural sciences, 47(7).

[31] Horpibulsuk, S., Miura, N., Nagaraj, T.S. (2003). Assessment of strength development in cement-admixed high water content clays with Abrams' law as a basis, Geotechnique, 53(4), pp. 439-444.

[32] Chian, S.C., Chim, Y.Q., Wong, J.W. (2017). Influence of sand impurities in cement-treated clays, Geotechnique, 67(1), pp. 31-41, DOI: 10.1680/jgeot.15.P.179.

[33] Consoli, N.C., Vendruscolo, M.A., Fonini, A., Rosa, F.D. (2009). Fiber reinforcement effects on sand considering a wide cementation range, Geotext. Geomembranes, 27(3), pp. 196-203, DOI: 10.1016/j.geotexmem.2008.11.005.

[34] Kutanaei, S.S., Choobbasti, A.J. (2016). Triaxial behavior of fiber-reinforced cemented sand, J. Adhes. Sci. Technol., 30(6), pp. 579-93, DOI: 10.1080/01694243.2015.1110073.

[35] Silva dos Santos, A.P., Consoli, N.C., Heineck, K.S., Coop, M.R. (2010). High-pressure isotropic compression tests on fiber-reinforced cemented sand, J. Geotech. Geoenvironmental Eng., 136(6), pp. 885-890.

[36] Park, S.-S. (2009). Effect of fiber reinforcement and distribution on unconfined compressive strength of fiber-reinforced cemented sand, Geotext. Geomembranes, 27(2), pp. 162-166.

[37] Guetif, Z., Bouassida, M., Tounekti, F. (2008).Numerical simulation of stone column installation using advanced elastoplastic model for soft soil. Proc. 5th Int. Symp. on 'Earth reinforcement':'New horizons in earth reinforcement, pp. 441-6.

[38] Gniel, J., Bouazza, A. (2008).Numerical modelling of small-scale geogrid encased sand column tests. Geotechnics of Soft Soils: Focus on Ground Improvement, CRC Press, pp. 155-162.

[39] Ahmed, S., Yasin, S.J.M. (2020). Design Charts for Strip Footing on Untreated and Cement Treated Sand Mat over Underlying Natural Soft Clay, Int. J. Geotech. Geol. Eng., 14(12), pp. 389-394.

[40] Greene, E.A. (n.d.). (2017). Excavation and retaining wall in clay soil using PLAXIS 3D, International Symposium on Construction Management and Civil Engineering. University skikda, Algeria.

[41] Guetif, Z., Bouassida, M., Tounekti, F. (2008). Numerical simulation of stone column installation using advanced elastoplastic model for soft soil, Conference, new horizons in earth reinforcement. Otani, Miyata, pp. 441-446.

[42] Tuan, N.A., Dat, N.T., Anh, N.D. (2020). The Application of Sheet Steel Piles Combined with Soil-Cement Piles to Stabilize a Deep Excavation Pit's Wall, Journal of Southwest Jiaotong University, 55(4).

DOI: 10.35741 /issn.0258-2724.55.4.13.

[43] Chan, D., Hsu, Y.S., Tan, R. (2021). Research data supporting "Improving semi-analytical predictions of long-term basement heave in over-consolidated clay", DOI: 10.17863/CAM.66654.

[44] Yusri, N.H., Chan, C.-M. (2021). Numerical Analysis of Senggarang Embankment Constructed Cement-CSP Stabilised Sandy Gravel, Prog. Eng. Appl. Technol., 2(1), pp. 444-452.

[45] Sakinah, N., Chan, C.M. (2021). Numerical Analysis of Senggarang Embankment Constructed with Cement-CSP Stabilied Silty Clay, Prog. Eng. Appl. Technol., 2(1), pp. 341-349.

[46] Bakari, D., Chan, C.M. (2021). Numerical Analysis of Senggarang Embankment Constructed with Cement-CSP Stabilised Sandy Clay, Prog. Eng. Appl. Technol., 2(1), pp. 373-82.

[47] Derrick, N., Srivastava, A.K. (2020). Effect of mesh size on soil-structure interaction in finite element analysis. International Journal of Engineering Research and Technology, 9(6). DOI: 10.17577/IJERTV9IS060655.

[48] Hemeda, S. (2021). Numerical analysis of geotechnical problems of historic masonry structures, Geotech. Geol. Eng., 39(3), pp. 2461-9.

[49] Diambra, A., Ibraim, E., Muir Wood, D., Russell, A.R. (2010). Fibre reinforced sands: Experiments and modelling, Geotext. Geomembranes, 28(3), pp. 238-250, DOI: 10.1016/j.geotexmem.2009.09.010.

[50] Guetif, Z., Bouassida, M., Debats, J.M. (2007). Improved soft clay characteristics due to stone column installation, Comput. Geotech., 34(2), pp. 104-111, DOI: 10.1016/j.compgeo.2006.09.008.

[51] Waterman, D. Chesaru, A. Bonnier, P. Galavi, V. (2013). Plaxis 3D tutorial manual, Netherlands, 3.

[52] Six, V., Mroueh, H., Shahrour, I., Bouassida, M. (2012). Numerical Analysis of Elastoplastic Behavior of Stone Column Foundation, Geotech. Geol. Eng., 30(4), pp. 813-825, DOI: 10.1007/s10706-012-9500-y.

[53] Anaokar, M., Mhaiskar, S. (2019). Numerical analysis of lime stabilized capping under embankments based on expansive subgrades, Heliyon, 5(9), pp. e02473.

[54] Das, B.M., Sivakugan, N. (2018). Principles of foundation engineering, Cengage learning. 12, pp. 438-524.

[55] Balasubramaniam, A.S., Cai, H., Zhu, D., Surarak, C., Oh, E.Y.N. (2010). Settlement of embankments in soft soils, 
Geotechnical Engineering Journal, 41(2), pp. 1-19.

[56] Abusharar, S.W., Zheng, J.-J., Chen, B.-G. (2009). Finite element modeling of the consolidation behavior of multicolumn supported road embankment, Comput. Geotech., 36(4), pp. 676-685.

[57] Ghorbani, A., Hosseinpour, I., Shormage, M. (2021). Deformation and stability analysis of embankment over stone column-strengthened soft ground, KSCE J. Civ. Eng., 25(2), pp. 404-416. 